This PDF is a selection from an out-of-print volume from the National Bureau of Economic Research

Volume Title: Tax Policy and the Economy, Volume 15

Volume Author/Editor: James M. Poterba, editor

Volume Publisher: MIT Press

Volume ISBN: 0-262-66122-5

Volume URL: http://www.nber.org/books/pote01-1

Publication Date: January 2001

Chapter Title: The Uneasy Marriage of Export Incentives and the Income Tax

Chapter Author: Mihir A. Desai, James R. Hines, Jr.

Chapter URL: http://www.nber.org/chapters/c10854

Chapter pages in book: (p. 41 - 94) 


\section{THE UNEASY MARRIAGE OF EXPORT INCENTIVES AND THE INCOME TAX}

\section{Mihir A. Desai}

Harvard University and NBER

James R. Hines, Jr.

University of Michigan and NBER

\section{EXECUTIVE SUMMARY}

This paper investigates the economic effect of tax incentives for American exports. These incentives include a partial tax exemption for export profits (available by routing exports through foreign sales corporations) and the allocation of some export profits to foreign-source income for purposes of U.S. taxation. The analysis highlights three important aspects of these policies. First, official figures appear to understate dramatically the tax expenditures associated with some U.S. export incentives. Correctly measured, total export benefits provided through the income tax are equivalent to a 1-percent ad valorem subsidy. Second, the 1984 imposition of more rigorous requirements for obtaining export subsidies through foreign sales corporations is contemporaneous with a significant change in the pattern of U.S. exports. Estimates imply that the 1984

We thank Naomi Feldman, Renata Kosova, and Rachel White for excellent research assistance; Thomas Barthold, Cynthia Belmonte Daniel Berman, Linda Goldberg, Scott Luttrell, Peter Merrill, Kimberly Pinter, James Poterba, Donald Rousslang, and Joel Slemrod for helpful comments and discussions; and the Lois and Bruce Zenkel Research Fund at the University of Michigan and the Division of Research at Harvard Business School for financial support. 
changes reduced U.S. manufacturing exports by 3.1 percent. Third, there were significant market reactions to the 1997 event in which the European Union charged that U.S. income tax provisions are inconsistent with World Trade Organization rules prohibiting export subsidies. Filing of the European complaint coincides with a 0.1-percent fall in the value of the U.S. dollar and steep drops in the share prices of major American exporters.

\section{INTRODUCTION}

On November 18, 1997, the European Union brought a complaint before the World Trade Organization (WTO), accusing the United States of violating the rules prohibiting members of the WTO from subsidizing exports. Europe maintained that provisions allowing American firms to route their export sales through tax-avoidance devices known as foreign sales corporations (FSCs) provide firms with export-contingent tax subsidies of roughly $\$ 4$ billion a year. The European Union argued that European firms are thereby unfairly disadvantaged in competition with American firms in foreign markets, and requested that the WTO require the United States to discontinue its program or else face WTO-imposed sanctions and penalties.

As trade disputes often do, the conflict between the European Union and the United States then moved to consultations between the two parties, in this case to no avail. Ultimately, in July 1998, the European Union lodged a more formal complaint, and over the following months the complaint was considered by a panel of WTO member countries. This WTO dispute resolution panel issued a report in May 1999 highly critical of the U.S. FSC rules, a report that was formally adopted by the WTO in February 2000.

While the World Trade Organization initially gave the United States a deadline of October 1, 2000 for legislating changes in the FSC provisions, a last-minute agreement extended the deadline for the resolution of this trade dispute through the middle of 2001. As of the time of this writing (October 2000), new American legislation that is intended to meet the WTO requirement is currently working its way through Congress. This new legislation formally scraps the existing system of FSCs while replacing it with an almost identical tax regime that adds minor sales incentives for foreign affiliates of American firms. Whether this legislation will ultimately become U.S. law, and, if it does so, whether the WTO and the European Union will be placated by this change, remain to be seen.

The purpose of this paper is to evaluate the economic importance of the American export incentives that lie at the heart of this dispute. Sec- 
tion 2 describes the two primary tax subsidies currently available to American exporters and their interaction. ${ }^{1}$ While FSCs allow firms to exempt a portion of export profits, separate provisions of the Internal Revenue Code allow exporters to allocate some fraction of profits on export sales to foreign-source income from the standpoint of U.S. taxation, thereby shielding the allocated portion from U.S. taxes. Section 3 traces the history of these tax subsidies and the disputes with which they are associated. Section 4 presents data on the extent to which American exporters enjoy the benefits of these two subsidies and the patterns of their use over the last two decades. It is noteworthy that, in spite of the WTO's focus on FSCs, the export incentive provided by the ability to allocate export profits to foreign-source income is quite possibly several times larger than the export incentive that arises from exempting a portion of export profits attributed to FSCs.

Section 5 evaluates the influence of export incentives on the behavior of American firms by considering the repercussions of two events: the establishment of FSCs and repeal of their predecessors, the domestic international sales corporations (DISCs) in 1984; and the filing of the complaint against the United States before the WTO in 1997. The evidence indicates that the transition from the DISC regime to the more administratively burdensome FSC program in 1984 led to reduced American exports. This reduced export activity is most pronounced in those sectors characterized by the greatest historical use of DISCs and those dominated by smaller exporters. This evidence suggests that transitions between export incentive regimes can be costly to American exporters, particularly small ones. By 1997, however, FSCs were well established, and the filing of a European complaint against the United States is associated both with a decline in the value of the U.S. dollar and with reduced share prices for American exporters. The magnitudes of these exchange-rate and stock price movements are consistent with the threatened removal of the widely used tax subsidy provided by the FSC program. Stock market reactions to the news of the European complaint are also indicative of the incidence of the export subsidy. Section 6 concludes the paper.

The magnitude and scope of U.S. export incentives warrant particular attention not simply because of the recent WTO dispute. The importance

1 The phrase "export subsidy" appearing here and elsewhere refers only to the economic concept of export subsidy (as used, for example, by Krugman and Obstfeld, 1991, pp. 108111) and not the legal concept of "export subsidy" as defined by WTO rules. A far more elaborate legal and textual analysis than that provided in this paper is necessary in order to determine whether or not U.S. export tax incentives represent "export subsidies" as de-
fined by the WTO. 
of trade to U.S. multinational corporations, domestic concern over outsourcing of production to foreign affiliates, the magnitude of FSC benefits received by large American exporters, ${ }^{2}$ and the chronic trade deficit facing the United States all suggest that the delivery of tax incentives to exporters will remain a central aspect of the public policy debate surrounding how corporations are taxed. Regardless of the outcome of the WTO dispute, it is worthwhile to evaluate the effects of the curious mechanisms that have evolved to subsidize American exports. ${ }^{3}$

\section{AMERICAN EXPORT INCENTIVES}

The U.S. tax system contains several provisions designed to encourage American firms to export goods from the United States to foreign countries. These provisions are dizzyingly complex, even by the standards of the Internal Revenue Code, as a result of which it can be difficult to establish their revenue impact and the incentives for which they are responsible. The goal of this section is to describe current export tax subsidies, their interactions, and the incentives they create for American firms.

The United States provides export tax subsidies through the exemption of export profits from U.S. taxation and through the ability to allocate export profits to foreign-source income. Exemption of a fraction of export profits from taxable income typically occurs by the routing of exports through a distinct entity such as an FSC. The alternative of allocating certain export profits to foreign-source income for the purposes of U.S. income taxation effectively shields such export profits from U.S. income taxation for those firms with excess foreign tax credits. While the allocation method is more generous for some taxpayers than the exemption method, it is also the more complicated of the two, and the focus of much less popular attention. Consequently, this section first reviews the U.S. tax provisions that permit the exemption of certain fractions of export income from U.S. taxation.

\subsection{Subsidy by Exemption of Income: FSCs and IC-DISCs}

Firms that export goods from the United States are entitled to do so in a legally roundabout fashion that enables them to exempt a fraction of export profits from taxation. While complying with the necessary rules can be cumbersome, the tax advantages are large enough to make it well

2 Oyola (2000) provides estimates of the contribution of FSC benefits to the net incomes of major exporters.

${ }^{3}$ Desai and Hines (2000a) examine the relative welfare consequences of delivering export subsidies on an ad valorem basis versus through the income tax. 
worth the while of most large American exporters to take advantage of this opportunity.

In order to benefit from this export tax subsidy, it is necessary to establish an FSC in an offshore location such as Guam, Barbados, or the Virgin Islands. For legal purposes, exports might then travel from the United States to their ultimate foreign destinations via the FSC. Hence, an American computer company that sells a computer manufactured in Texas to a buyer in northern Italy first sells the computer to its FSC located in Guam, which in turn sells the computer to the buyer in Italy. The computer does not travel to Guam in the course of this sale, nor are the FSC offices located in Guam typically very active; instead, these are largely paper transactions. In the course of these transactions, the FSC located in Guam earns a profit; some of this profit is immediately subject to U.S. taxation, but a fascinating $\frac{15}{23}$ is forever exempt, thereby providing a tax subsidy for exporters. ${ }^{4}$

For an American firm whose profits are fully taxed by the United States at the 35-percent corporate tax rate, there is a benefit associated with making the FSC's share of total export profits as large as possible. ${ }^{5}$ Consider the case in which the American computer manufacturer produces its computer for $\$ 1,500$ in the United States and sells the computer in Italy for $\$ 2,000$. Without the use of an FSC, all $\$ 500$ of this profit is subject to U.S. taxation at the 35-percent rate. With the FSC involved in the transaction, the FSC might purchase the computer for $\$ 1,885$ and sell it in Italy for $\$ 2,000$, thereby earning an export profit of $\$ 115$. The American exporting company therefore will owe taxes on the remaining $\$ 385$ of export profits, and its FSC will likewise owe U.S. taxes on $\frac{8}{23} \times \$ 115$, or $\$ 40$. The remaining $\$ 75\left(\frac{15}{23} \times \$ 115=\$ 75\right)$ of FSC profit is exempt from U.S. taxation, and, since FSCs are located in offshore jurisdictions that impose no taxes, the $\$ 75$ is also exempt from foreign taxation. At a tax rate of 35 percent, this translates into a tax saving of $\$ 26.25$. Since the law fixes the $\frac{15}{23}$ exclusion ratio, it is therefore in the taxpayer's interest to establish that the FSC export profits are as large as possible. ${ }^{6}$

As a consequence, U.S. law also requires taxpayers to calculate the profit of an FSC based on methods that limit the exempt fraction of

4 Alternatively, the Guamanian FSC might not take title to the export property, but instead receive a commission for facilitating the export sale. According to data reported by Belmonte (2000), $21 \%$ of FSCs in 1996 bought and sold export property, while the remaining
$79 \%$ simply received commissions for export sales. 5 The tax benefits of exporting through FSCs are available to all corporations in the United
States, including those that are foreign-owned.

6 Taxpayers are not entitled to defer U.S. taxation of FSC profits. Corporations exporting
through FSCs instead receive tax benefits in the form of through FSCs instead receive tax benefits in the form of the exemption of $\frac{15}{23}$ of FSC profits. 
total export profits. Taxpayers are entitled to choose among several different methods of distributing export profits between the exporter located in the United States and its offshore FSC. The first, and most commonly used, method is simply to assign the FSC a commission equal to 23 percent of export profits. In the previous example, $\$ 115$ of FSC profit was arrived at through the application of this method. It is on the basis of the prevalence with which exporters assign their FSCs 23 percent of export profits, together with the $\frac{15}{23}$ exclusion ratio, that FSCs are typically described as exempting 15 percent of export profits from taxation.

The second method is to assign the FSC a commission equal to 1.83 percent of gross export sales. The profits assigned to the FSC under this second method are required not to exceed twice those that would have been assigned the FSC under the 23-percent profit allocation. The third profit calculation method is to use arm's-length pricing between the American exporter and the FSC to determine the amount of export income for which the FSC is responsible. Since FSCs typically do very little on their own to facilitate export sales, it is difficult to justify large FSC profits on the basis of the third method, and as a result, it is seldom used.

In addition, taxpayers are also entitled to use what are known as marginal costing techniques in order to determine the size of export profits when calculating FSC income. With marginal costing, export profits equal the difference between the ultimate sales prices of export property and the American exporter's marginal cost of production. For this purpose, marginal production costs include only direct material and labor costs, thereby excluding selling costs and various fixed costs such as interest expense and general administrative expenses. While the ability to expand the size of export profits is very appealing to taxpayers, marginal costing is subject to two important limitations. The first is that marginal costing cannot be used to allocate more profit to an FSC than the firm actually earns on its exports, after taking into account selling costs and a pro rata share of various fixed costs. The second limitation is that the profit rate on exports, as defined by marginal costing, and measured as a fraction of export sales, must not exceed the firm's overall profit rate, defined as the ratio of the firm's combined (domestic plus foreign) profits to total sales. As a result, it is useful to calculate FSC income based on marginal costing only when the profit rate on exports is lower than the profit rate for the firm as a whole.

Taxpayers are not required to use the same methods to calculate FSC profits for all export transactions, but can instead pick and choose among methods to maximize tax benefits. In particular, it is possible to 
combine export transactions involving similar products in calculating export profits.

There are restrictions on the kinds of export sales that may be routed through an FSC, as well as restrictions on the details of FSC management. In order to be eligible for the tax benefits offered by FSCs, export property must have no more than 50 percent of non-U.S. content and cannot be intended for ultimate use in the United States. Qualifying export property must be tangible, meaning that patents, copyrights, trademarks, and like property cannot receive FSC treatment. ${ }^{7}$ Furthermore certain specific items are ineligible for FSC treatment. These include oil and gas products (other than petrochemicals), 50 percent of military equipment sales, and various idiosyncratic commodities, including unprocessed softwood timber, western red cedar, and horses for slaughter shipped by sea. ${ }^{8}$

FSCs are subject to strict administrative requirements. U.S. law requires FSCs to be corporations organized in foreign countries or qualifying U.S. possessions. ${ }^{9}$ FSCs cannot have more than 25 shareholders, must have at least one foreign director, and must hold all board of directors and shareholder meetings outside the United States. An FSC must use a foreign bank account and maintain a foreign office, complete with a permanent set of books, though the foreign office need not be located in the FSC's country of incorporation. There is, however, no requirement that any important decisions be made in an FSC's foreign office. The FSC is required to participate in foreign sales activity, meaning at least one of solicitation, negotiation, and concluding sales contracts-though this requirement is made rather less burdensome by the FSC's ability to hire its related supplier or another company to undertake this activity on the FSC's behalf. The FSC is also required to incur at least half of the direct costs of foreign sales, including advertising and sales promotion, processing orders, transportation, and the like. Again, an FSC is entitled to hire other firms, including related parties, to perform these activities on its behalf.

\footnotetext{
${ }^{7}$ Exporters of intangible property such as patent rights are typically compensated in the form of royalties that are treated as foreign-source income under U.S. law and therefore effectively untaxed if received by domestic taxpayers with excess foreign tax credits. See Hines (1995) for an analysis of the economic effect of this treatment of royalty income. Additionally, the Taxpayer Relief Act of 1997 permitted computer software to receive FSC treatment starting in 1998.
}

${ }^{8}$ Importantly, slaughter horses shipped by air remain eligible for FSC treatment.

${ }^{9}$ FSCs may be incorporated in U.S. possessions other than Puerto Rico, countries covered by the Caribbean Basin Economic Recovery Act of 1983, or countries whose bilateral tax treaties with the United States contain exchange-of-information provisions. 
While the FSC rules are designed to facilitate the use of FSCs by all exporters, the administrative burdens they impose can be daunting for small exporters. As a result, legislation establishing FSCs also authorized the creation of small FSCs, shared FSCs, and IC-DISCs, which serve to facilitate the exports of small companies. Small FSCs offer the same tax benefits as regular FSCs with looser foreign materiality requirements; they can be used by firms with export receipts of less than $\$ 5$ million. Similarly, a small FSC or a traditional FSC can be shared by up to 25 exporters and thereby provide the benefits of an FSC to exporters incapable of supporting the foreign materiality requirements individually. Taxpayers also have the option of routing up to $\$ 10$ million of export sales each year through an interest charge domestic international sales corporation, or IC-DISC. An exporter is able to defer domestic tax liability on export profits earned by sales routed through an IC-DISC and not distributed to the parent company, though it is necessary to pay the U.S. government interest (at Treasury bill rates) on any undistributed profits of an ICDISC. The administrative requirements of IC-DISCs are quite modest, and their use typically permits small exporters to obtain the benefits of low-interest-rate loans from the government equal to the amount of tax liabilities generated by exports.

\subsection{Subsidy by Allocation of Income: Export Source Rules}

An entirely separate type of export subsidy is available to American multinational firms with excess foreign tax credits. The nature of the subsidy is that part or all of export profits can be treated as foreignsource income for the purpose of U.S. income taxation. This export subsidy is more generous to qualifying firms than is the subsidy provided by the use of FSCs. Since many American multinational firms have excess foreign tax credits, ${ }^{10}$ and the parent companies of American multinational firms account for 58 percent of all U.S. exports of goods, ${ }^{11}$ it follows that this export subsidy is potentially quite impor-

10 Grubert, Randolph, and Rousslang (1996) report that firms with excess foreign tax credits received 33 percent of the foreign income of American corporations in 1984, and 66 percent in 1990, which follows the U.S. tax rate reduction in 1986. They note that even this 66-percent figure is smaller than the 79 percent predicted right after 1986, and conjecture that contemporaneous foreign tax law changes along with the endogenous behavior of American companies may account for the difference. They also note that the fraction of foreign income received by firms with excess foreign tax credits appears to be falling over time, reaching 35 percent in 1992. In a subsequent study, Grubert (2001) reports additional evidence that changes in taxpayer behavior (such as greatly expanded receipts of foreignsource royalty income) account for much of the unexpectedly low incidence of excessforeign-tax credit status after 1986.

11 See the data for 1997 reported in Mataloni $(1999$, p. 14). 
tant. Notably, this subsidy is not available to American exporters that are not multinational firms.

In order to understand the tax subsidy available from the foreignsource rules, and the circumstances under which taxpayers might be eligible for the associated tax benefits, it is necessary to review certain aspects of U.S. taxation of the foreign income of American taxpayers. A brief description of some of the relevant features follows. ${ }^{12}$

2.2.1 The Foreign Tax Credit Almost all countries tax income generated by economic activity that takes place within their borders. In addition, many countries-including the United States-tax the foreign incomes of their residents. In order to prevent double taxation of the foreign income of Americans, U.S. law permits taxpayers to claim foreign tax credits for income taxes (and related taxes) paid to foreign governments. ${ }^{13}$ These foreign tax credits are used to offset U.S. tax liabilities that would otherwise be due on foreign-source income. The U.S. corporate tax rate is currently 35 percent, so an American corporation that earns $\$ 100$ in a foreign country with a 10-percent tax rate pays taxes of $\$ 10$ to the foreign government and $\$ 25$ to the U.S. government, since its U.S. corporate tax liability of $\$ 35$ (35 percent of $\$ 100$ ) is reduced to $\$ 25$ by the foreign tax credit of $\$ 10$.

\subsubsection{Tax Deferral Americans are permitted to defer U.S. tax liabilities} on certain unrepatriated foreign profits until they receive such profits in the form of dividends. ${ }^{14}$ This deferral is available only on the active business profits of American-owned foreign affiliates that are separately incorporated as subsidiaries in foreign countries. The profits of unincorporated foreign businesses, such as those of American-owned branch banks in other countries, are taxed immediately by the United States. Interest, rent, and royalty income received from foreign countries also represents foreign-source income on which U.S. tax obligations cannot be deferred.

\footnotetext{
12 Portions of this description are excerpted from Hines $(1991,1999 a)$.

13 The United States is not alone in taxing the worldwide income of its residents while permitting them to claim foreign tax credits. Other countries with such systems include Greece, Italy, Japan, Norway, and the United Kingdom. Under U.S. law, taxpayers may claim foreign tax credits for taxes paid by foreign firms of which they own at least 10 percent, and only those taxes that qualify as income taxes are creditable.
}

${ }^{14}$ Deferral of home-country taxation of the unrepatriated profits of foreign subsidiaries is a common feature of systems that tax foreign incomes. Other countries that permit this kind of deferral include Canada, Denmark, France, Germany, Japan, Norway, Pakistan, and the United Kingdom. 
U.S. tax law contains provisions designed to prevent American firms from delaying the repatriation of lightly-taxed foreign earnings. ${ }^{15}$ These tax provisions apply to controlled foreign corporations, which are foreign corporations owned at least 50 percent by American individuals or corporations who hold stakes of at least 10 percent each. Under the Subpart F provisions of U.S. law, the passive income of controlled foreign corporations is "deemed distributed," and therefore immediately taxable by the United States, even if not repatriated as dividend payments to American parent firms. ${ }^{16}$

2.2.3 Excess Foreign Tax Credits Because the foreign tax credit is intended to alleviate international double taxation, and not to reduce U.S. tax liabilities on profits earned within the United States, the foreign tax credit is limited to U.S. tax liability on foreign-source income. For example, an American firm with $\$ 200$ of foreign income that faces an U.S. tax rate of 35 percent has a foreign-tax-credit limit of $\$ 70$ (35 percent of $\$ 200$ ). If the firm pays foreign income taxes of less than $\$ 70$, then the firm will be entitled to claim foreign tax credits for all of its foreign taxes paid. If, however, the firm pays $\$ 90$ of foreign taxes, then it will be permitted to claim no more than $\$ 70$ of foreign tax credits.

Taxpayers whose foreign tax payments exceed the foreign tax credit limit are said to have excess foreign tax credits; the excess foreign tax credits represent the portion of their foreign tax payments that exceed the U.S. tax liabilities generated by their foreign incomes. Taxpayers whose foreign tax payments are smaller than their foreign-tax-credit limits are said to be in excess limit or to have deficit foreign tax credits. American law permits taxpayers to use excess foreign tax credits in one year to reduce their U.S. tax obligations on foreign-source income in either of the two previous years or in any of the following five years. ${ }^{17}$

15 In spite of these provisions, it appears that American multinationals selectively repatriate profits from foreign affiliates based on tax considerations. See the evidence reported in Hines and Hubbard (1990), Altshuler and Newlon (1993), Altshuler, Newlon, and Randolph (1995), and Hines (1999b).

16 Subpart $F$ income consists of income from passive investments (such as interest and dividends received from investments in securities), foreign-base-company income (that arises from using a foreign affiliate as a conduit for certain types of international transactions), income that is invested in United States property, money used offshore to insure risks in the United States, and money used to pay bribes to foreign government officials. American firms with foreign subsidiaries that earn profits through most types of active business operations, and that subsequently reinvest those profits in active lines of business, are not subject to the Subpart F rules, and are therefore able to defer U.S. tax liability on their foreign profits until they choose to remit dividends at a later date.

17 Foreign tax credits are not adjusted for inflation, so they are generally the most valuable if claimed as soon as possible. Barring unusual circumstances, firms apply their foreign tax 
In practice, the calculation of the foreign-tax-credit limit entails certain additional complications, notable among which is that total worldwide foreign income is used to calculate the limit. This method of calculating the foreign-tax-credit limit is known as worldwide averaging. A taxpayer has excess foreign tax credits if the sum of worldwide foreign income tax payments exceeds this limit. The combination of worldwide averaging and selective repatriation of dividends from subsidiaries located in countries with differing tax rates implies that the average foreign tax rate used to calculate the foreign-tax-credit limit need not equal the average foreign tax rate faced by a firm's foreign affiliates. ${ }^{18}$ The ability of multinational firms to adjust the amount of foreign income received in non-dividend forms (such as interest and royalties) contributes to their control over whether or not they have excess foreign tax credits. ${ }^{19}$ This flexibility is further enhanced by the source rules discussed in the next subsection.

\subsubsection{Source Rules and Excess Credits Firms with excess foreign tax} credits benefit whenever they can treat income earned by activities undertaken in the United States as having a foreign source for purposes of U.S. income taxation, since those firms are effectively untaxed on such income. The benefit to a firm with excess foreign tax credits of allocating income to foreign source is illustrated by the comparison presented in Table 1. The American multinational firm in this example earns $\$ 40$ by exporting from the United States and an additional $\$ 100$ from the operations of its foreign affiliate. The affiliate is located in a country with a 50-percent tax rate, which, since it exceeds the U.S. tax rate of 35 percent, implies that the parent company has $\$ 15$ of excess foreign tax credits. If export profits are treated as domestic income, then the firm's $\$ 40$ of export income is fully taxed at the domestic tax rate of 35 percent, resulting in a tax liability of $\$ 14$. If instead the credits against future years only when unable to apply them against either of the previous
two years.

Firms paying the corporate alternative minimum tax (AMT) are subject to the same rules, with the added restriction that the combination of net operating loss deductions and foreign tax credits cannot reduce AMT liabilities by more than 90 percent. It is noteworthy that, since the AMT rate is only 20 percent, firms subject to the AMT are considerably more likely to have excess foreign tax credits than are firms that pay the regular corporate tax. 18 Average foreign income tax rates paid by foreign affiliates reflect investnent decisions as well as transfer pricing practices that affect the location of reported taxable income. There is ample evidence, surveyed by Hines (1999a), that both types of decisions are sensitive to
their tax implications.

19 Hines $(1994,1995)$ and Grubert (1998) offer evidence that foreign-source interest and royalty receipts are sensitive to tax considerations. 


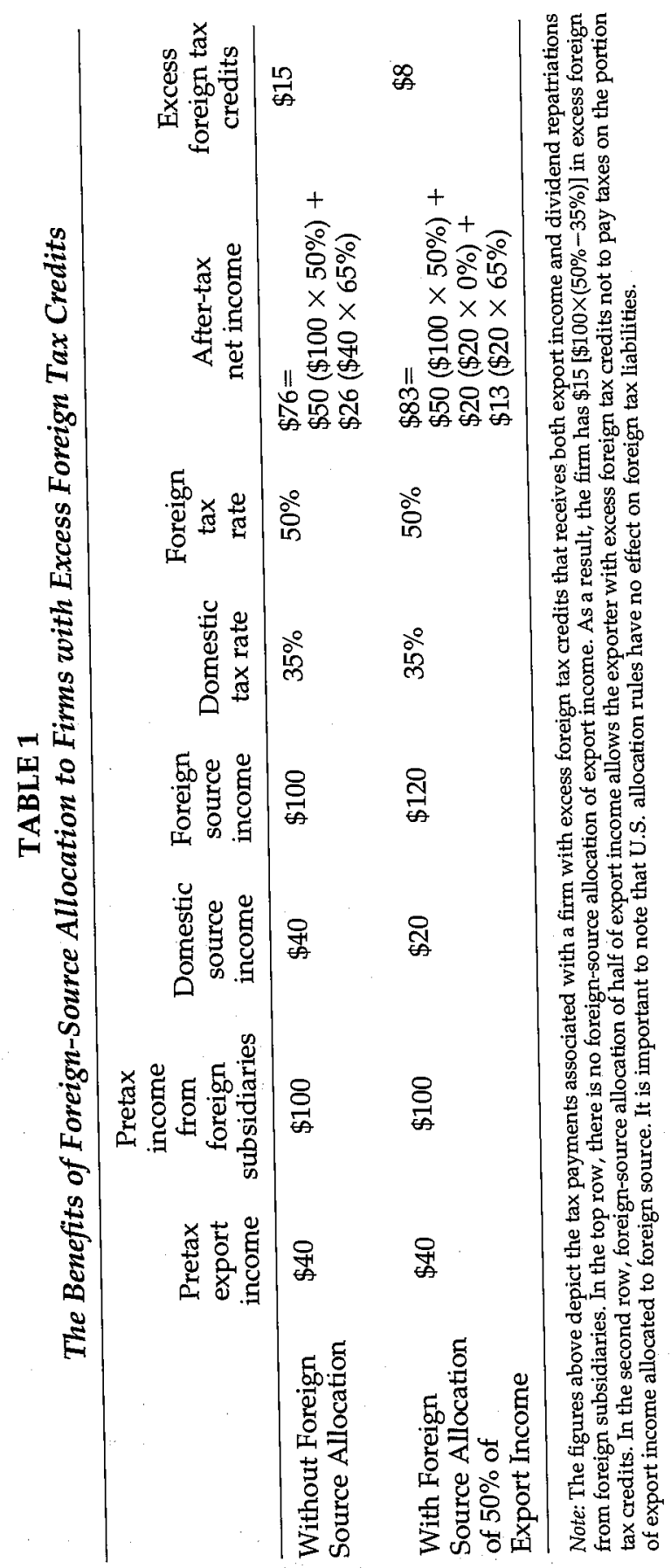


exporter can characterize 50 percent of export profits as having foreign source, then $\$ 7$ of the firm's excess foreign tax credits can be applied against the U.S. tax liability on export profits, leaving a net tax liability of $\$ 7$ on export profits. An important aspect of this benefit is that foreign governments do not coordinate their taxation of export income with the United States. Thus, the election by an American taxpayer to treat $\$ 20$ of export profits arising from sales to Italy as having foreign source for U.S. tax purposes will have no effect on any Italian taxes that the taxpayer may owe.

U.S. tax law embodies the curious principle that the location of income arising from a sale is determined, in part, by the site of the sale rather than the site of production. For a firm with minimal production activities in the United States and selling only for export, all or most of its income can be characterized as foreign income under section 862 of the Internal Revenue Code. If this firm is part of a controlled group with excess foreign tax credits, then this firm's profits from exports will be entirely untaxed by the United States. ${ }^{20}$ Most exporters produce some of their export property (rather than simply buying and selling goods for export), and under U.S. law then have a combination of domestic and foreign income. For these taxpayers, Section 863(b) of the Internal Revenue Code provides that half of export-related profits will be deemed to have foreign source if the taxpayer arranges to pass the export title in the foreign location rather than in the United States. Therefore, firms with excess foreign tax credits are eligible to avoid U.S. taxation of 50 percent of their export profits by taking advantage of the opportunity provided under section $863(\mathrm{~b})$.

\subsection{Incentives for Exporters}

American exporters are faced with the enviable choice between two export subsidies: the partial exemption of export income earned using an FSC, and the allocation of half of export income to foreign source under section $863(\mathrm{~b})$. For firms with deficit foreign tax credits, the export source rules do not offer the prospect of reduced U.S. tax liabilities, since income allocated to foreign source is nonetheless immediately taxable by the United States. Such firms do better to route their exports through FSCs, in which case they are eligible for a 15-percent exclusion of export

20 It is not known to what extent American exporters use such domestically-located foreign sales subsidiaries to allocate 100 percent of export income to foreign source. While strict application of arm's-length pricing between a domestic producer and a domesticallytransfer pricing within the U.S. is monitored. 
Subsidy by Exemption: FSC

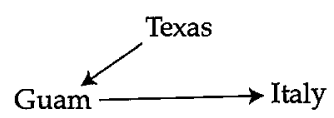

Approximately $15 \%$ of profits exempt due to allocation of profits to FSC and 15/23 exemption

Available to most firms
Subsidy by Allocation: 863(b)

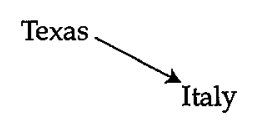

$50 \%$ of profits allocated to foreign source and these profits face no taxation if exporter has excess foreign tax credits

Valuable only to firms with excess foreign tax credits
Joint Use

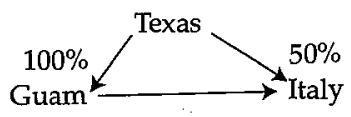

$40 \%$ of profits exempt due to full use of FSCs (15\%) and partial use of $863(\mathrm{~b})$ $(25 \%=50 \% \times 50 \%)$

Available to all firms but full advantage only to firms with excess foreign tax credits

Requires creation of FSC

Requires creation of FSC

\section{FIGURE 1. Overview of Incentives for Exporters}

profits from U.S. taxation. ${ }^{21}$ Firms with excess foreign tax credits minimize their taxes by avoiding the use of FSCs altogether, and instead using $863(\mathrm{~b})$ to allocate 50 percent of export profits to foreign source, since doing so effectively excludes 50 percent of export profits from U.S. taxation.

The first two columns of Figure 1 summarize the relevant differences between the exemption and allocation methods of subsidizing exports for a Texan manufacturer exporting a computer to an Italian customer. Regardless of a firm's excess-foreign-tax-credit status, a 15-percent exemption of export profits is available through the creation of an FSC and the routing of exports through the FSC. In contrast, if the exporter is a multinational firm with excess foreign tax credits, 50 percent of export profits can escape taxation through the use of 863(b). The final column of Figure 1 outlines the interaction of these provisions and is discussed in Section 3.2.

There is an important complication to this otherwise simple story, stemming from the fact that a firm's excess-foreign-tax-credit status changes over time and is itself a function of many decisions that the firm makes every year. Such decisions include where to locate foreign operations, whether to finance foreign operations with debt or equity, how

21 Firms with very low profit margins on their exports can exclude up to 30 percent of their export profits from U.S. taxation by electing to determine FSC income with the 1.83percent rule. Firms have incentives to make this election whenever export profits represent less than 7.96 percent of export sales prices. 
many dividends to repatriate from each of its foreign subsidiaries, and what costs (such as interest expenses or R\&D expenses) the firm will incur in the United States and allocate in part against foreign income. As a result, the distinction between a firm with excess foreign tax credits and one with deficit foreign tax credits is perhaps more a matter of degree, reflecting different circumstances and incentives, than it is a stark characteristic of a firm carrying clear-cut implications. Since excess foreign tax credits can be carried back two years and forward five, a firm's excess-foreign-tax-credit status in a given year is less consequential than the pattern of its foreign tax credits over time and the costs it incurs in taking the actions necessary to change its status. ${ }^{22}$

\section{HISTORY OF U.S. EXPORT SUBSIDIES}

The United States has a long history of providing tax subsidies for American exports. ${ }^{23}$ This section recounts the history of U.S. export subsidies provided by the exemption of export profits, subsidies provided by the allocation of export profit to foreign-source income, and the recent controversy over the compatibility of FSCs with WTO rules. This history of export subsidies is also mapped out in Table 2.

\subsection{Tax Exemptions for Export Profits}

The original idea behind exempting export profits from U.S. taxation was to encourage trade with strategically important parts of the world. The Revenue Act of 1939 authorized the creation of China trade corporations, which permitted taxpayers to exclude from U.S. tax a fraction of profits earned on exports to China. The Revenue Act of 1942 authorized the creation of Western Hemisphere trade corporations, which similarly exempted from U.S. taxation a fraction of profits earned on trade within the Western Hemisphere.

In practice, exporters could frequently generate their own export tax incentives by routing exports through sales affiliates located in offshore tax havens. With adept use of transfer pricing, ${ }^{24}$ a fraction of export

\footnotetext{
22 See, for example, Scholes and Wolfson (1992) for an analysis of the costs and benefits of undertaking actions that affect foreign-tax-credit status.
} 23 See Hufbauer (1992) for an interpretive survey of the history of American export
subsidies.

24 There is controversy over the extent to which American companies can reduce their tax obligations by adjusting transfer prices on transactions between members of a controlled group. U.S. law, and the laws of most industrialized countries, requires taxpayers to use arm's-length prices in transactions between related parties. Arm's-length prices are difficult to establish for many transactions, however, leaving taxpayers some latitude in setting 


\section{TABLE 2}

History of U.S. Export Incentives

\begin{tabular}{l} 
Subsidy by exemption \\
\hline 1939 - China trade corporations \\
1942-Western Hemisphere trade \\
corporations
\end{tabular}

Subsidy by allocation

1918-Initiation of allocation rules

1954, 1957-Use of independent

factory prices (IFP) or 50/50 allocation

1962-Subpart F Rules

1971-Creation of DISCs

1972-EC complaint to GATT

1976, 1982-Reduction of DISC bene-

fits and GATT rulings

1984-Initiation of FSCs and IC-DISCs

1986-Cut in corporate tax rate

1988-Regulations issued to tighten use of IFP

1993-Court decisions backing 50/50 allocation

1997-WTO complaint

profits could be attributed to the sales affiliates, thereby removing this fraction from the taxable income of the parent company. If the sales affiliate is located in a jurisdiction with low or zero taxes, then its profits are untaxed. The introduction of the U.S. Subpart F rules in 1962 threatened to reduce greatly the value of this tax-avoidance opportunity on the part of exporters, since profits earned by foreign sales affiliates are subject to immediate U.S. taxation under Subpart F. As a result, the 1962

transfer prices. Grubert and Mutti (1991), Hines and Rice (1994), and Clausing (2001), among others, offer evidence that the profitability and trade patterns of the foreign affiliates of American companies are consistent with tax-motivated adjustment of international transfer prices. 
legislation permitted taxpayers to route exports through export trade corporations, the income of which is not subject to immediate U.S. taxation as long as this income does not exceed 150 percent of export promotion expenses (or 10 percent of gross receipts, whichever is less). Furthermore, export trade corporations are required to reinvest their profits in export trade assets in order to continue to defer U.S. tax obligations. Due to these requirements, and the attractive alternatives available to American exporters, export trade corporations are seldom used.

Concern over the languid performance of American exports led Congress in 1971 to establish domestic international sales corporations (DISCs). A certain fraction of export profits could be allocated to the DISC rather than the domestic exporter. The income of a DISC was tax-exempt until distributed to its domestic parent company, and DISCs were required under the 1971 legislation to distribute only half of their profits. The remaining half of DISC profits could therefore be deferred from U.S. taxation indefinitely. Exporters could choose among three alternatives in assigning export profits to the DISC: 50 percent of export profits, 4 percent of gross export sales, or those profits that could be justified on the basis of arm's-length pricing between the exporter and its DISC. ${ }^{25}$ The third of these alternatives was of course very seldom used, given the inability tojustify large DISC profits based on the economic activity undertaken by DISCs. Of the first two, the 50-percent method was the election of choice for most exports. Together, the 50 -percent method of determining DISC profits and the 50-percent distribution requirement implied that 25 percent of export profits could be exempt from domestic taxation.

In response to budgetary pressures, Congress subsequently reduced the tax subsidy available from routing exports through DISCs. The Tax Reform Act of 1976 permitted taxpayers to claim deductions only for exports in excess of firm-specific targets equal to 67 percent of average exports in the preceding four years. The Tax Equity and Fiscal Responsibility Act of 1982 further reduced DISC benefits by requiring DISCs to distribute to their taxable parents 57.5 percent of income, leaving only 42.5 percent available for indefinite deferral.

Unfortunately for the DISC program, the General Agreement on Tariffs and Trade (GATT), of which the United States was a member, proscribed export subsidies, including tax subsidies taking the form of reduced income taxes on export profits. The European Community filed a complaint with the GATT over the DISC program in July 1972. The United States responded by filing a complaint with GATT against Belgium, France and

25 Of course, the law contained many details beyond these, for example permitting taxpayers to augment DISC profits by 10 percent of export promotion expenses. 
the Netherlands, claiming that the tax systems of those countries indirectly allowed exporters to avoid domestic tax on export profits by using transfer prices to shift export profits into foreign sales subsidiaries located in tax havens. In November 1976, GATT panels issued reports finding that the DISC program, as well as the European tax practices, violated GATT rules. The GATT membership accepted these findings in December 1981, subject to the qualifications that home countries are entitled to provide double-tax relief for foreign income taxes paid, including the exemption of foreign profits from home-country taxation, as long as international transactions are based on arm's-length prices. The United States maintained that these qualifications implied that the DISC was permissible under GATT rules, but acknowledged that continuing its DISC program in the wake of the GATT ruling had the effect of undermining GATT. In October 1982 the United States announced its intention to eliminate the DISC program, and did so in creating FSCs with the Deficit Reduction Act of $1984 . .^{26}$ FSCs were fashioned to require more extensive foreign activity than DISCs in the hope that their foreign presence would blunt GATT criticism of the program.

\subsection{Export Source Rules}

The allocation of export profits between domestic and foreign sources was originally codified by the Revenue Act of 1918, which provided that all export profits represent foreign-source income as long as the relevant marketing activity takes place abroad. The Tax Reform Act of 1954, and subsequent Treasury regulations in 1957, imposed a new requirement that taxpayers use "independent factory prices" to determine the location of export profits. Exporters selling goods for which arm's-length (independent factory) prices are available must use such prices to determine the amount of export profit. Thus, an exporter producing a good in the United States for $\$ 200$ and selling it abroad for $\$ 280$ might use a comparable good selling for $\$ 250$ to establish an independent factory price. Consequently, $\$ 50$ of the associated export profit would be assigned to domestic source, and \$30 to foreign source. In the (large number of) cases for which such independent factory prices do not exist, or arguably do not exist, taxpayers with domestic and foreign income were entitled to allocate half of export profits to foreign source, provided only that the title to the export property passed hands in the foreign location. As a practical matter, exporters were generally able to allocate to foreign source half of their export income.

26 The 1984 Act provided that undistributed DISC income as of the end of 1984 was to be distributed to parent companies without any accompanying tax obligation of the recipients. 
The 1986 U.S. tax rate reduction increased the numbers of taxpayers with excess foreign tax credits and impelled the U.S. Treasury to issue regulations in 1988 and 1989 intended to limit the benefits available from allocating export profits to foreign source. These new regulations tightened the requirement that taxpayers use independent factory prices to determine export profits that are subject to allocation under Section 863(b). The regulations gave taxpayers the alternative of routing exports through an FSC, in which case full FSC benefits were available, plus the taxpayer could subject half of export profits to the 50-50 split under Section 863(b). This alternative would effectively exempt from U.S. taxation 40 percent of the export profits of firms with excess foreign tax credits, since $863(\mathrm{~b})$ treatment of half of export profits makes 25 percent foreign-source income, to which can be added the 15-percent FSC exemption. While exporters selling goods for which there are no obvious market comparables might do better by determining the source of all export profits according to independent factory prices, the Treasury strongly hinted its willingness to confront such elections. This alternative is summarized in the final column of Figure 1.

Taxpayers nonetheless eagerly continued to allocate half of export income to foreign source under Section 863(b), which led to high-profile court confrontations with the Treasury and ultimately a retreat on the part of the U.S. government. ${ }^{27}$ Court decisions in 1993, along with 1997 Treasury regulations, confirmed the ability of exporters to allocate half of export profits to foreign source. While confrontations with the Treasury were no longer a threat, taxpayers continued to have the option of routing exports through FSCs while jointly allocating half of export profits through 863(b).

\subsection{The WTO Controversy}

Ongoing trade disputes between the United States and Europe took an interesting turn on November 18, 1997, when the European Union

27 In a 1991 opinion, the Tax Court originally sided with the IRS interpretation of the 863(b) statute requiring the use of independent factory prices, but two important 1993 cases were decided in favor of taxpayers taking liberal interpretations of the statute. As U.S. Treasury official Rousslang (1994, p. 1049) commented at the time, "The possibility that the taxpayer may be forced to use an independent factory price appears to have been significantly reduced, however, by recent court findings in Intel $v$. Commissioner, 100 T.C. No. 39 (June $28,1993)$. The finding appears to require the U.S. parent to sell the exports through a foreign branch before it is required to use an independent factory price. Few exports are sold through foreign branches; most are sold to foreign subsidiaries or to unrelated parties." Macdonald (1999, p. 470) notes later that "As a practical matter, the 1993 Intel and Phillips decisions left taxpayers with a choice of methods [including the 50-50 profit split method] because they could typically structure their transactions to avoid creating an independent factory price." 
lodged a complaint with the WTO alleging that the American FSC program represented an illegal export subsidy. Contemporaneous observers noted that the European complaint represented a retaliation for successful American claims that European import regimes for bananas and hormone-treated beef violated WTO rules. The original FSC complaint was followed by inconclusive consultations between the United States and the European Union on December 17, 1997, and continued unfruitful consultations on February 10, 1998. On July 23, 1999 the WTO's Dispute Resolution Panel issued its interim report stating that the American FSC program violated WTO rules. The July 23 report also indicated that the United States would be required to rescind its FSC provisions by October 1, 2000 or else face retaliatory penalties. Following the appearance of the interim report, the European Union and the United States together requested on August 6, 1999 that the panel review the precise aspects of the interim report. The WTO's final ruling against the United States appeared on September 17, 1999.

On October 28, 1999, the United States indicated its intention to appeal the WTO's report, and filed a formal notice of appeal. The U.S. appeal was withdrawn on November 2,1999, but refiled on November 26,1999 . Following rounds of submissions by all parties to the dispute, as well as oral hearings, the WTO formally ruled on the legality of FSCs on February 24, 2000, finding that the FSC program violates WTO rules and must be replaced by October 1, 2000.

The American response came quickly. On February 28, 2000 American Treasury Secretary Lawrence Summers said that the United States would not abandon its program of subsidizing exports, and would instead start consultations with the European Union to determine appropriate compensation. On April 7, 2000, the United States informed the Dispute Resolution body of its intention to implement its recommendations consistently with WTO obligations. Finally, on September 13, 2000, the House of Representatives voted in favor of legislation (H.R. 4986, the FSC Repeal and Extraterritorial Income Exclusion Act of 2000) that would effectively retain current export subsidies while adding small subsidies for sales by foreign affiliates of American multinational corporations.

\section{THE MAGNITUDE OF TAX INCENTIVES FOR U.S. EXPORTS}

This section profiles the magnitude and scope of tax incentives for American exporters over the last two decades. Accordingly, it captures two major events in the legislative history of international taxation and export subsidies: the repeal of the DISC provisions in 1984, and the passage of 
the Tax Reform Act of 1986, which reduced U.S. tax rates and thereby increased the likelihood that an American multinational firm had excess foreign tax credits. In describing the scope of export incentives, this section separately considers exemption of export profits through distinct entities (DISCs, IC-DISCs, and FSCs) and subsidies through interactions between export source rules and the foreign tax credits [863(b) allocations].

\subsection{DISCs, IC-DISCs, and FSCs}

Table 3 and Figure 2 present available information on numbers and activities of DISCs, IC-DISCs, and FSCs used by American taxpayers in $1980,1983,1987,1992$, and 1996 by industry category. ${ }^{28}$ Data for 1980 and 1983 report the activities of DISCs, while data for subsequent years report the total activity of FSCs and IC-DISCs together. ${ }^{29}$ In 1996, American taxpayers used 5,136 FSCs and IC-DISCs to export goods worth $\$ 290.5$ billion. Eighty-nine percent of those entities and 86 percent of those exports were in manufacturing industries in 1996. The prevalence of FSCs and IC-DISCs can be expressed as the share of all U.S. exports that employ these entities. In 1996, 49.8 percent of all U.S. exports passed through these entities. Their use is more prevalent in the nonmanufacturing sector, where 71.5 percent of exports employ these entities, while only 47.2 percent of manufactured exports employ them. ${ }^{30}$ Within manufacturing, the usage of FSCs and IC-DISCs appears heavily weighted toward four sectors-chemicals, non-electrical machinery, electrical machinery and electronics, and transportation equipment.

The dynamics of the use of these distinct export entities suggests that the repeal of the DISC legislation in 1984 had a large impact on U.S. exporters. From 1983 to 1987, the number of export entities fell by 60.7 percent and the volume of exports passing through these entities fell by 36.7 percent. This drop in exports employing FSCs and IC-DISCs was more pronounced in non-manufactured products, where there was a 67.1-percent reduction between 1983 and 1987. While the number of export-vehicle tax returns within manufactured products dropped by 60.7 percent, the total value of exports employing these entities dropped by only 26.9 percent, suggesting that smaller exporters were less likely to replace DISCs with FSCs and IC-DISCs immediately. Finally, the share of all U.S. exports employing these export vehicles dropped from 70.9 to

28 Data for FSC usage are only available for years 1987, 1992, and 1996. DISC data are available more regularly prior to the repeal of the DISC legislation in 1984.

${ }^{29}$ For 1992, data represent the sum of FSC activity in 1992 and IC-DISC activity in 1991. ${ }^{30}$ Non-manufacturing industries that employ FSCs include agricultural services, computer software, and leasing services. 


\section{TABLE 3}

The Use of DISCs, FSCs, and IC-DISCs from 1980 to 1996 by Industry

\begin{tabular}{|c|c|c|c|c|c|c|c|}
\hline \multirow[b]{2}{*}{ Industry } & \multicolumn{5}{|c|}{ Number of returns } & \multicolumn{2}{|c|}{ Change (\%) } \\
\hline & 1980 & 1983 & 1987 & 1992 & 1996 & $83-87$ & $87-96$ \\
\hline Total & 8,665 & 9,663 & 3,798 & 4,053 & 5,136 & -60.7 & 35.2 \\
\hline Non-manufactured products & 1,052 & 1,073 & 419 & 437 & 560 & -61.0 & 33.7 \\
\hline Manufactured products & 7,613 & 8,589 & 3,379 & 3,525 & 4,557 & -60.7 & 34.9 \\
\hline Food and kindred products & 336 & 352 & 198 & 187 & 160 & -43.8 & -19.2 \\
\hline Tobacco manufactures & 12 & 20 & 10 & 12 & 10 & -50.0 & 0.0 \\
\hline Textile mill products & 284 & 263 & 50 & 58 & 72 & -81.0 & 44.0 \\
\hline Apparel, etc. & 180 & 172 & 17 & 17 & 52 & -90.1 & 205.9 \\
\hline Lumber, etc., except furniture & 198 & 292 & 55 & 139 & 139 & -81.2 & 152.7 \\
\hline Furniture and fixtures & 42 & 39 & 27 & 28 & 39 & -30.8 & 44.4 \\
\hline Paper and allied products & 160 & 184 & 70 & 72 & 66 & -62.0 & -5.7 \\
\hline Printing and publishing, etc. & 126 & 122 & 74 & 43 & 79 & -39.3 & 6.8 \\
\hline Chemicals and allied products & 621 & 625 & 219 & 302 & 334 & -65.0 & 52.5 \\
\hline $\begin{array}{l}\text { Rubber and misc. plastics } \\
\text { products }\end{array}$ & 162 & 282 & 82 & 45 & 126 & -70.9 & 53.7 \\
\hline Leather and leather products & 79 & 43 & 32 & 32 & 36 & -25.6 & 12.5 \\
\hline $\begin{array}{l}\text { Stone, clay, glass, and con- } \\
\text { crete products }\end{array}$ & 78 & 78 & 29 & 48 & 51 & -62.8 & 75.9 \\
\hline Primary metal industries & 281 & 222 & 111 & 106 & 165 & -50.0 & 48.6 \\
\hline Fabricated metal products & 773 & 820 & 230 & 239 & 331 & -72.0 & 43.9 \\
\hline Machinery, except electrical & 1,448 & 1,467 & 525 & 622 & 984 & -64.2 & 87.4 \\
\hline $\begin{array}{l}\text { Electrical machinery and } \\
\text { equipment }\end{array}$ & 1,354 & 1,655 & 745 & 708 & 835 & -55.0 & 12.1 \\
\hline Transportation equipment & 441 & 537 & 251 & 294 & 486 & -53.3 & 93.6 \\
\hline $\begin{array}{l}\text { Professional and scientific in- } \\
\text { struments }\end{array}$ & 439 & 636 & 313 & 350 & 322 & -50.8 & 2.9 \\
\hline Miscellaneous manufactures & 545 & 743 & 326 & 178 & 253 & -56.1 & -22.4 \\
\hline
\end{tabular}

Note: For 1980 and 1983, data represent total numbers of DISC returns. For 1987, 1992 and 1996, data represent the numbers of FSC and IC-DISC returns combined. For 1992, data represent numbers of IC-DISC returns for 1991 plus 1992 FSC returns. The last two columns present the percentage change from 1983 to 1987 and from 1987 to 1996.

Sources: Belmonte (2000), Holik (1995, 1997), and U.S. Treasury $(1988,1992)$.

36.0 percent between 1983 and 1987, with the non-manufacturing sector dropping from 93.2 to 31.5 percent and the manufacturing sector dropping from 65.8 to 36.8 percent. Thus, the repeal of the DISC legislation appears to have had a sizable impact on U.S. exporters and particularly smaller U.S. exporters. This link between the repeal of DISC and subsequent U.S. export performance is explored further in section 5.1. Subsequent to 1987, and particularly after 1992, the frequency of FSC and IC-DISC use by exporters has grown considerably and is approaching the 1983 DISC level. 


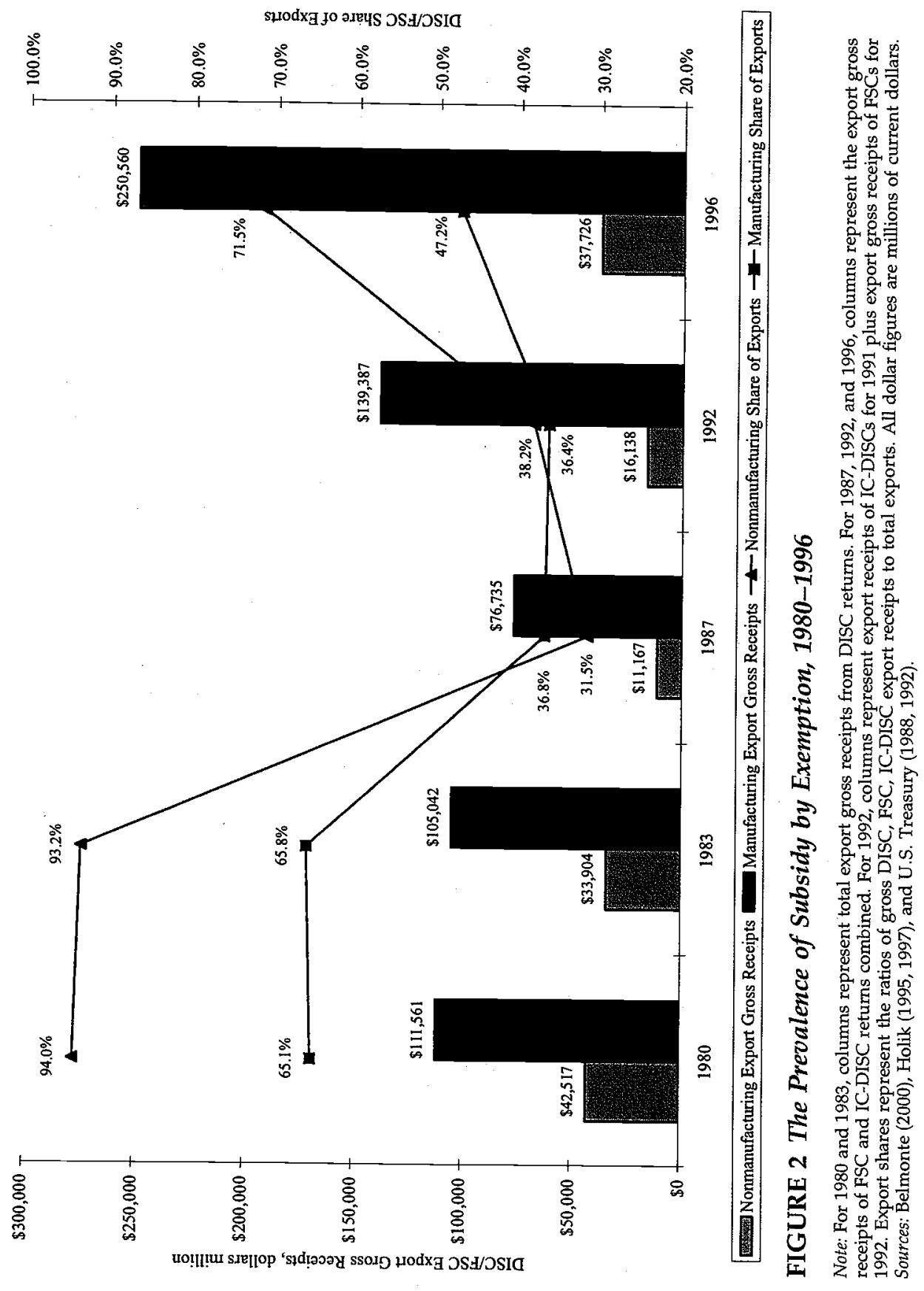


The evolution of FSC usage is explored further in Figure 3 and Table 4. Figure 3 illustrates that the upward surge in numbers of FSCs did not begin until the early 1990s. Information on numbers of FSCs is available on an annual frequency, making it possible to depict the growth of FSC usage, as in Figure 3. Of course, changes in the number of FSCs need not coincide with important changes in the economic influence of the FSC program, since major exporters are very likely to have availed themselves of the advantages of the FSC program from its inception.

Table 4 provides details on the location, pricing methods, and parental characteristics of FSCs. FSCs are high concentrated in five attractive foreign locations-the U.S. Virgin Islands, Barbados, Guam, Jamaica, and the Netherlands-which together account for 95.0 percent of FSC tax returns and 95.3 percent of export receipts in 1996. While the U.S. Virgin Islands continues to be the most popular location for an FSC, Barbados appears to have attracted larger exporters in recent years.

The pricing methods chosen by FSCs exhibit differences based on sizes of exporters. In 1996, exclusive usage of either the 1.83-percent grossreceipts method or the 23-percent combined-taxable-income method accounted for 73.6 percent of FSC tax returns but only 29.8 percent of export receipts. Larger exporters show signs of opportunistically employing combinations of pricing methods, as 17.6 percent of returns and 59.6 percent of exports employ combinations of the gross-receipts, combinedtaxable-income, and marginal-costing methods. The importance of large exporters in understanding the impact of the FSC program is underscored by the fact that parents with over $\$ 1$ billion in assets account for only 16.3 percent of FSC returns but 74.3 percent of export gross receipts. Table 5 further details the usage of FSCs by size of parent assets. While most corporations use only one FSC, large parents appear to use more than one FSC. ${ }^{31}$ Overall, 29.2 percent of all non-financial corporations with assets of more than $\$ 250$ million employ FSCs, further indicating the dominance of large firms as FSC users.

\subsection{Source Rules and the Use of 863(b)}

Figure 4 provides details on the magnitude of export subsidies that were derived through the use of foreign-source allocation rules by U.S. exporters in 1980, 1984, 1990, 1992, and 1996. ${ }^{32}$ In 1996, $\$ 27.4$ billion of export income was treated as foreign-source income under $863(\mathrm{~b})$. Figure 4 also

31 The use of more than one FSC by a single firm is commonly the short-term result of a merger between two companies, each of which has an FSC.

32 Data on 863(b) allocations are provided in the Corporate Foreign Tax Credit data releases provided in the SOI Bulletin. Prior to 1992, these releases are biannual; after 1992 they are provided annually. Data for 1988 were not collected. 


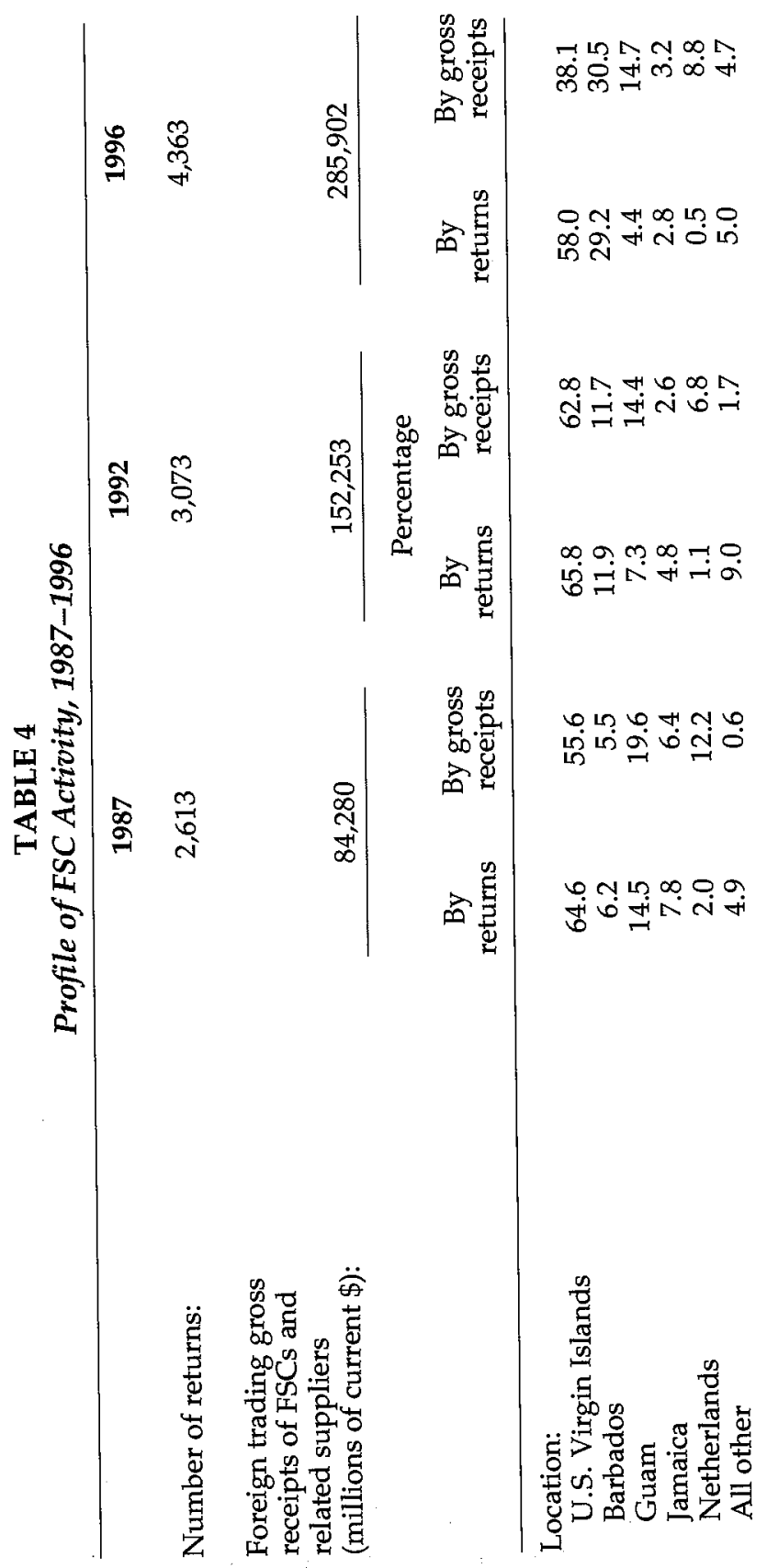




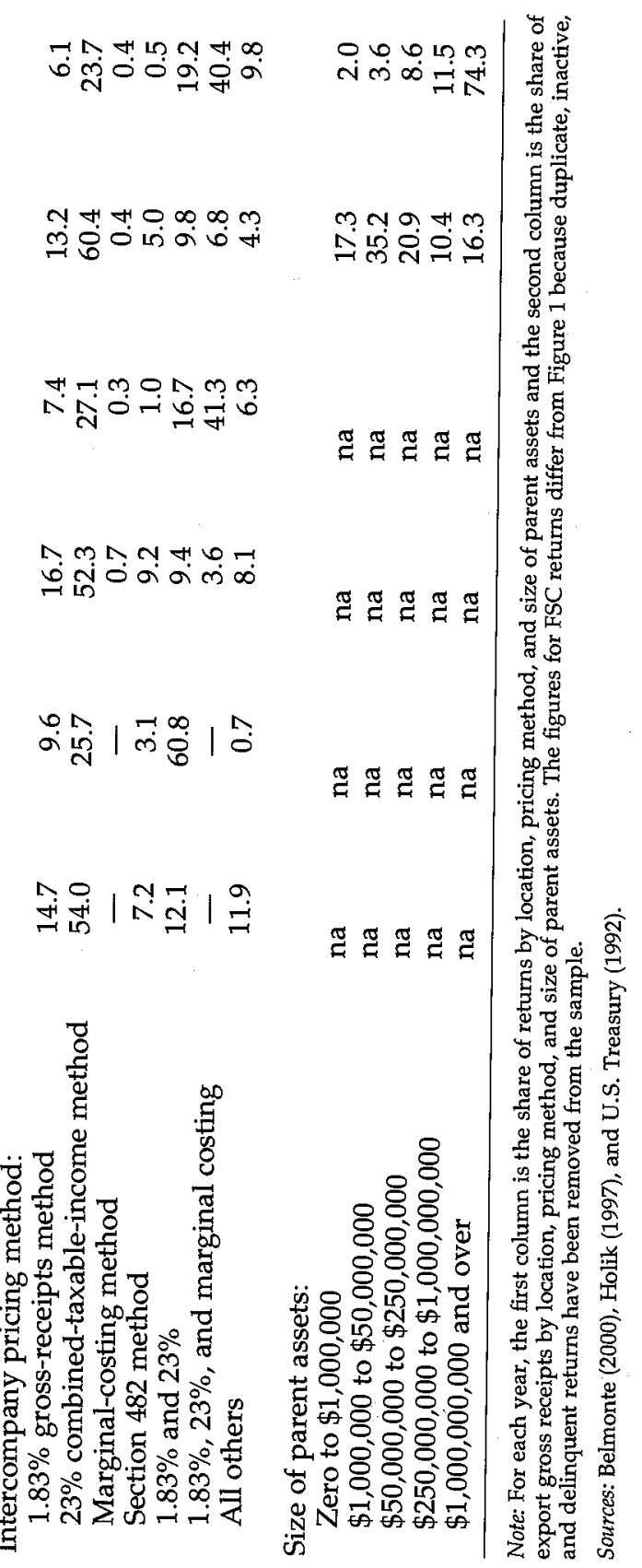




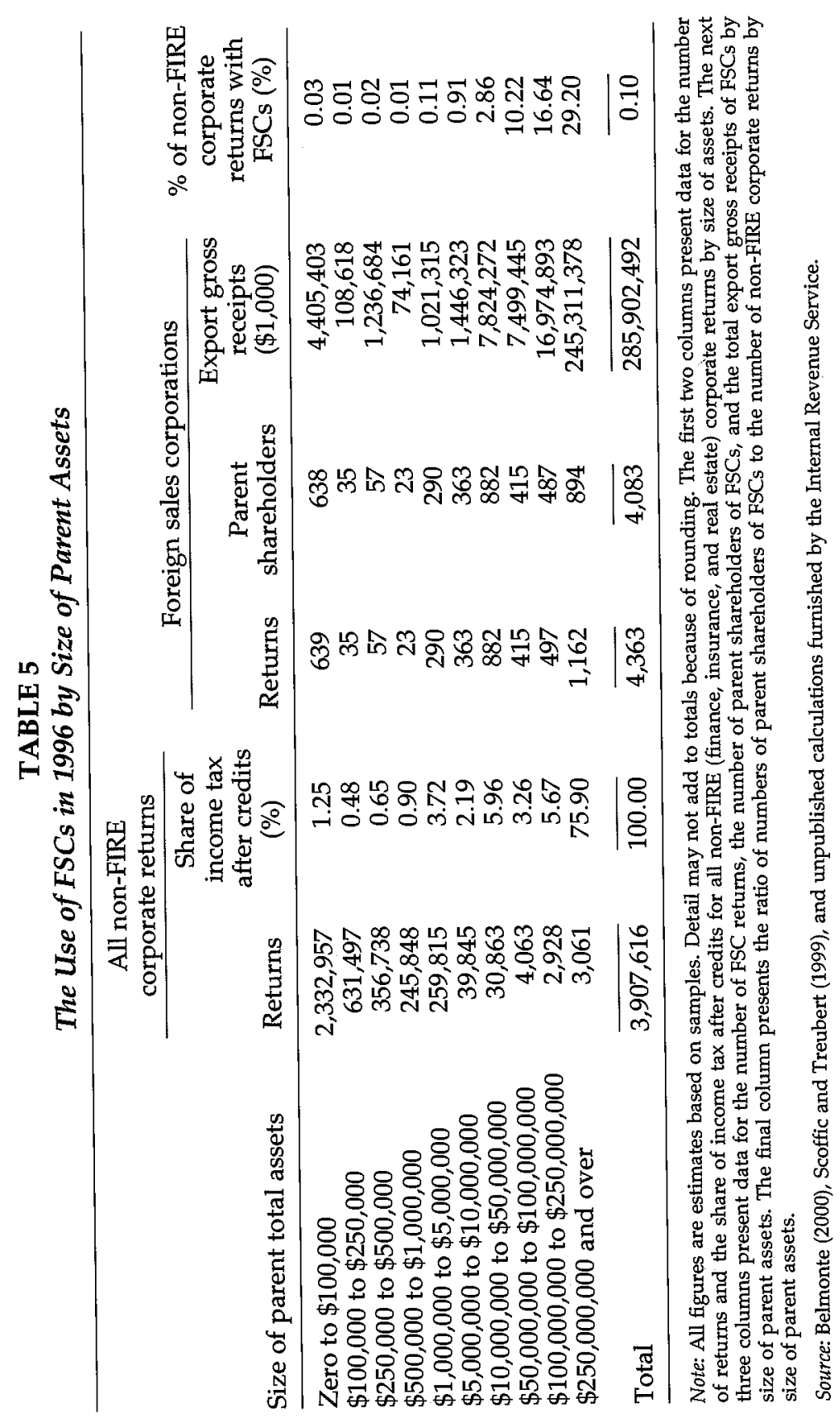


present ratios of $863(\mathrm{~b})$ income to total taxable foreign profits, showing that, in 1996, 863(b) allocations represented 18.9 percent of foreign taxable profits. While manufacturing accounted for 66.4 percent of total 863(b) income, the transportation and FIRE sectors accounted for 17.4 and 10.9 percent of the income allocated. As is also true of FSC usage in the manufacturing sector, 863(b) manufacturing income is highly concentrated in chemicals, electronics, instruments, and motor vehicles. Industry figures for 1990, 1992, and 1996, not reported here, suggest that exporters are opportunistic in their usage of $863(\mathrm{~b})$ allocations, as usage varies considerably from year to year.

Despite these year-to-year variations, it is clear that the period from 1984 to 1990 represents a dramatic change in the use of $863(\mathrm{~b})$ allocations. Across all sectors, gross 863(b) income grew almost ninefold, and manufacturing 863(b) allocation grew almost sevenfold, from 1984 to 1990. As a share of foreign taxable income, 863(b) allocations grew from 3.7 to 22.5 percent between 1984 and 1990 across all sectors, and from 4.92 to 20.29 percent in manufacturing. Across most sectors, the share of taxable income represented by 863(b) allocations reached a peak in 1992 and receded slightly by $1996 . .^{33}$

This trend in use of $863(\mathrm{~b})$ allocations can be at least partly explained by the overall trend in the excess-foreign-tax-credit status of American multinationals. The Tax Reform Act of 1986 (TRA) reduced the U.S. corporate statutory tax rate from 46 to 34 percent, forcing a number of U.S. multinationals into excess-foreign-tax-credit status. Accordingly, the appeal of using 863(b) allocations grew considerably after TRA and would have dominated the use of FSCs for any firm with excess foreign tax credits. Since electing to allocate export income entirely through 863(b) prevents the use of FSCs, the relatively limited growth of FSCs from 1987 through the early 1990s is consistent with incentives created by the increasing incidence of excess credit status. After the early 1990s, FSCs resumed their rapid growth, suggesting, along with other evidence, that U.S. multinationals were less likely to have excess foreign tax credits by the early 1990 s.

The relative importance of FSCs, IC-DISCs, and the 863(b) source allocation rules for U.S. exporters is explored in Table 6 for manufacturing

33 The comparability of this data across years is limited by a reporting change between 1984 and 1990. Specifically, figures for 1980 and 1984 represent net 863(b) allocations after deductions while figures for 1990, 1992 and 1996 are gross 863(b) allocations. Conversations with IRS officials and filers suggest that there exists considerable confusion about what relevant deductions are for 863 (b) income. Nonetheless, consideration of definitely allocable deductions in years after 1990 does not mitigate the conclusion that $863(\mathrm{~b})$ activity
increased substantially between 1984 and 1990 . 


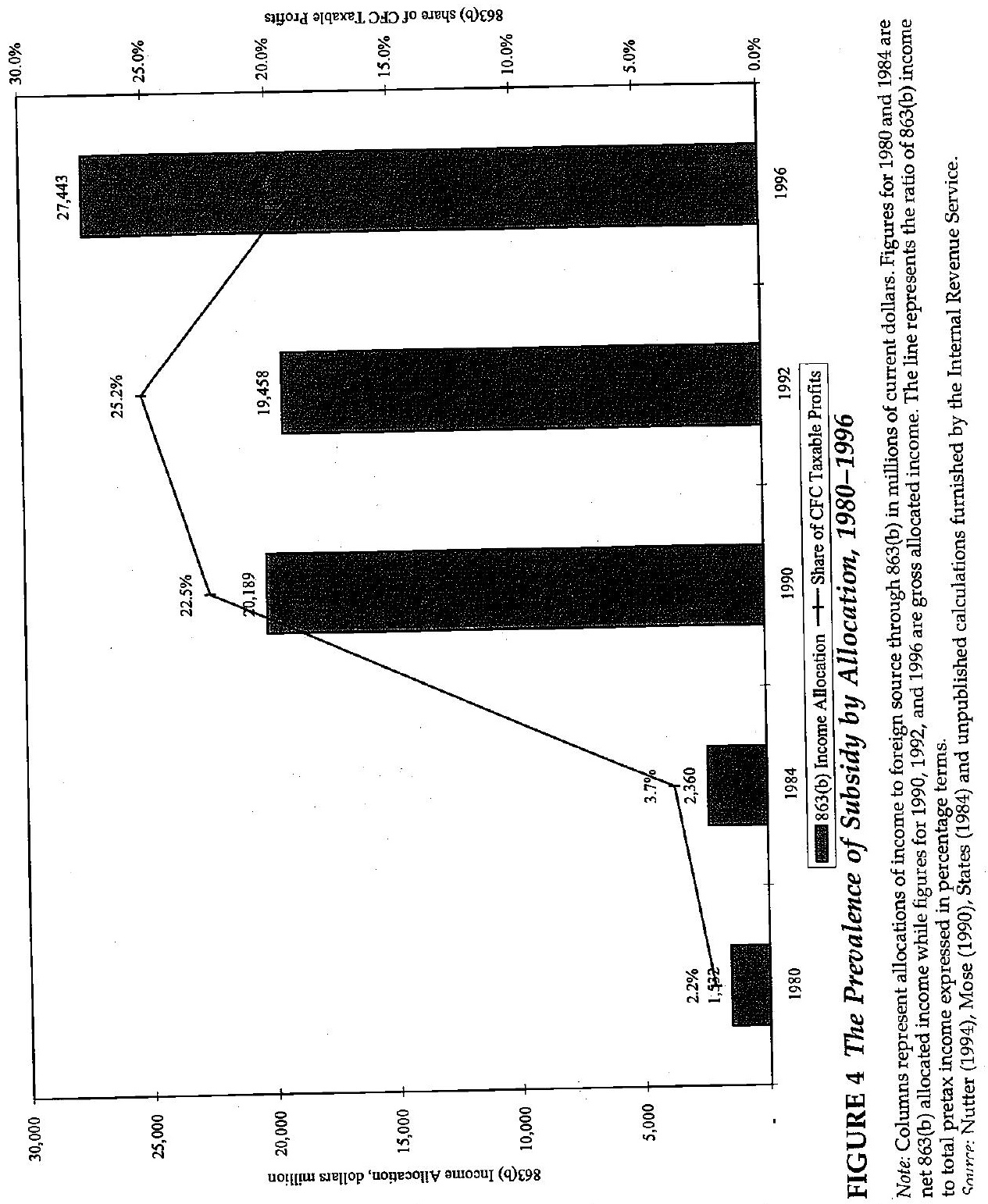




\section{TABLE 6 \\ The Prevalence of Export Subsidies in Manufacturing Exports, 1992 and 1996}

\begin{tabular}{lcc}
\hline & 1992 & 1996 \\
\hline FSC/IC-DISC export gross receipts & $\$ 383,082$ & $\$ 530,484$ \\
FSC/IC-DISC share & $\$ 139,387$ & $\$ 250,650$ \\
\hline FSC manufacturing net exempt income & $36.39 \%$ & $47.25 \%$ \\
Corresponding FSC export profits & $\$ 3,615$ & $\$ 7,368$ \\
$863(b)$ income jointly employing FSCs & $\$ 24,100$ & $\$ 49,120$ \\
Total 863(b) income allocation & $\$ 6,025$ & $\$ 12,280$ \\
863(b) income exclusively employing 863(b) & $\$ 13,145$ & $\$ 18,229$ \\
SOI pretax margin for manufacturing & $\$ 7,120$ & $\$ 5,949$ \\
Corresponding 863(b) exports & $6.19 \%$ & $8.20 \%$ \\
863(b) share & $\$ 230,048$ & $\$ 145,098$ \\
\hline
\end{tabular}

Note: Dollar figures are millions of current dollars. Total manufacturing exports represents exports for all U.S. manufacturers. FSC/IC-DISC export gross receipts is total exports for FSCs and IC-DISCs combined. FSC/IC-DISC share is the ratio of FSC/IC-DISC export gross receipts to total manufacturing exports. FSC manufacturing net exempt income is the export profit that is not taxed due to the use of a FSC. Corresponding FSC export profits is FSC net exempt income divided by 15 percent and represents total FSC export profits. $863(\mathrm{~b})$ income jointly employing FSCs is corresponding FSC export profits divided by four according to the assumption that half of FSC export profits employ joint use of 863(b). Total 863(b) income allocation represents total manufacturing 863(b) income. 863(b) income exclusively employing $863(\mathrm{~b})$ is the difference between total $863(\mathrm{~b})$ income allocation and $863(\mathrm{~b})$ income jointly employing FSCs. SOI pretax margin for manufacturing is the ratio of pretax profits to business receipts for all manufacturing firms. Corresponding 863(b) exports is 863(b) income exclusively employing 863 (b) multiplied by two and divided by the SOI pretax margin for manufacturing. 863(b) share is the ratio of corresponding 863(b) exports to total manufacturing exports. Source: Belmonte (2000), Holik (1995, 1997), and unpublished calculations furnished by the Internal
Revenue Service.

exports. While FSC data provide export receipt figures, isolating the exports that employ $863(\mathrm{~b})$ is complicated by two factors. First, if taxpayers make joint use of FSCs and 863(b) as described above, then income allocated to $863(\mathrm{~b})$ does not represent exports that uniquely use $863(\mathrm{~b})$ as an export subsidy. Second, data are available for the income allocated through $863(\mathrm{~b})$ but not for the corresponding exports. In order to circumvent these difficulties, the calculations reported in this table presume that half of all FSC exporters jointly use 863(b) and that the profitability 
of 863(b) exports is represented by the overall profitability of U.S. manufacturing firms. ${ }^{34}$ Table 6 shows that, under these assumptions, 863(b) was the dominant export subsidy for manufacturers in 1992, covering more than 60 percent of their exports. By 1996, however, the relative use of FSCs had increased substantially.

\subsection{The Revenue Impact of FSCs and 863(b)}

Figure 5 provides official estimates of the actual and projected tax expenditures for the FSC and 863(b) export subsidies from 1985 to $2005 .{ }^{35}$ While the tax expenditures related to FSCs reported in Figure 5 follow a steady upward trend, tax expenditures associated with 863(b) allocations are reported only after 1985 and dominate FSC expenditures until 1993. Beginning in 1993, 863(b) expenditures drop precipitously, and subsequently follow a more orderly pace, suggesting a change in estimating methodology. By 2005, FSCs are estimated to constitute an annual tax expenditure of $\$ 5.5$ billion, while the $863(\mathrm{~b})$ source allocation rules are estimated to constitute an annual tax expenditure of $\$ 1.6$ billion. For the five years from 1995 to 2000 , the combination of the two programs provided tax expenditures that grew at a compound annual rate of 13 percent.

The methodology employed by the U.S. Treasury to calculate the figures reported in Figure 5 may considerably underestimate the tax expenditures associated with these subsidies, particularly the subsidy implicit in the $863(\mathrm{~b})$ allocation rules. ${ }^{36}$ The potential understatement of the tax expenditures for export tax subsidies is apparent from the magnitude of

34 The actual figures for the joint use of FSCs and 863(b) are not known.

35 For the purpose of these estimates, "tax expenditures" consist of tax revenue forgone due to the provision of special export tax incentives.

36 The values of these tax subsidies are calculated by using actual tax returns to evaluate the changes in tax liabilities that would accompany repeal of the FSC or 863(b) provisions, assuming that taxpayer behavior did not respond to the changes. Also, the calculated revenue effects of the subsidies ignore the implicit values of excess-tax-credit carryforwards and other intertemporally dependent tax characteristics. Since a firm's excessforeign-tax-credit status is, to a certain degree, a function of its endogenous decisions, and since foreign-tax-credit carryforwards and carrybacks are valuable to firms that anticipate changes in the future, it follows that it would be a mistake to attribute zero value to $863(\mathrm{~b})$ allocations made by firms with deficit foreign tax credits in the current year-yet that is what the official budget figures do. Since rational taxpayers who appear to have deficit foreign tax credits always have the option of routing their exports through FSCs, it follows that they would not elect to allocate all of their export profits through $863(\mathrm{~b})$ unless by doing so they anticipate receiving tax benefits at least as great as those available from using FSCs. Rousslang (1994) describes the U.S. Treasury's method of calculating the revenue cost of the 863(b) sales source rules. These calculations have been criticized by Hufbauer and DeRosa (1997) on the grounds that they fail to incorporate the beneficial revenue effects of encouraging domestic export activity, a criticism to which Rousslang (1997) replies. 


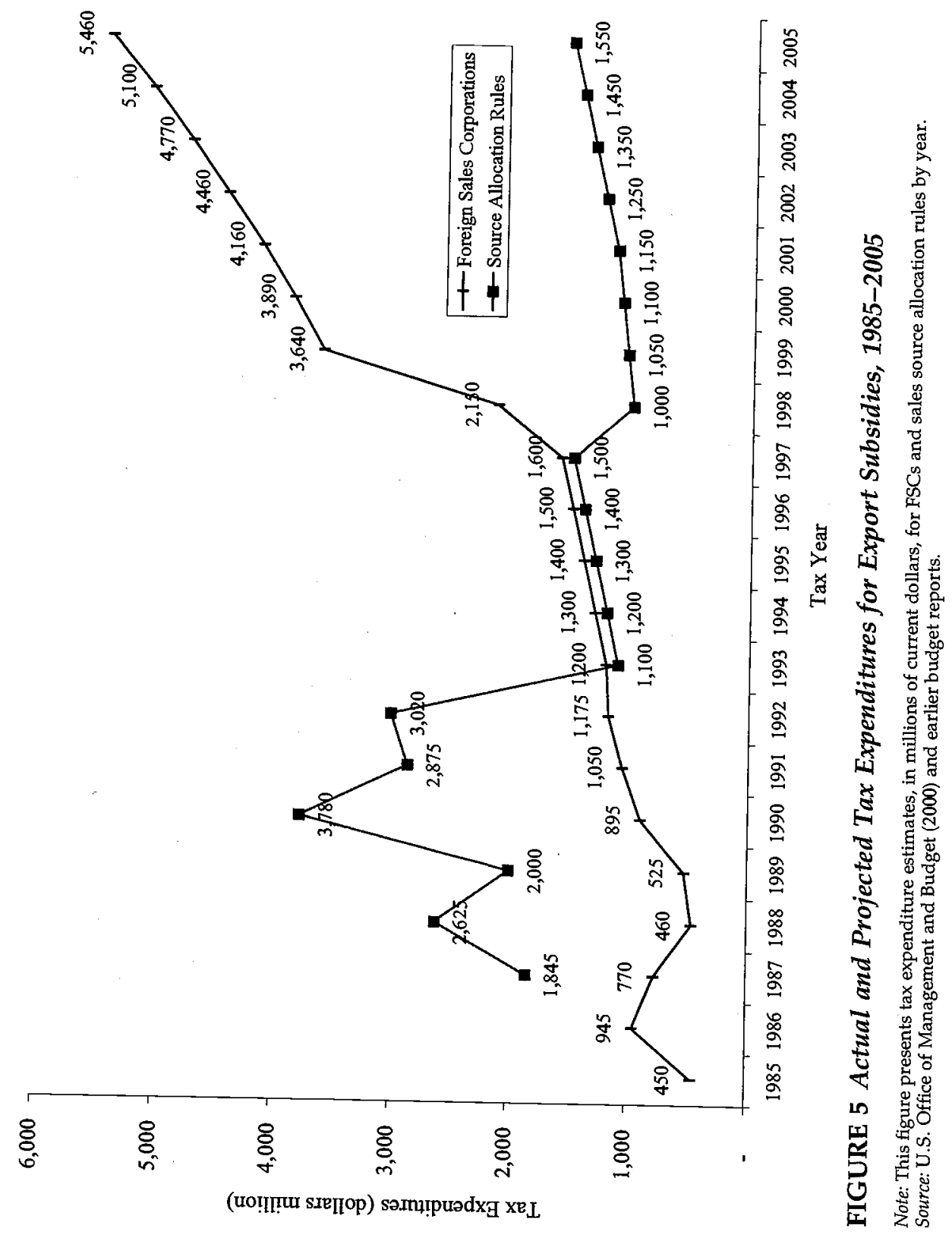


863(b) income, which is $\$ 27.4$ billion in 1996 (the last year for which figures are available). If taxpayers using 863(b) were able to take full tax advantage of their allocations, then the tax benefit associated with this allocation would equal ( $\$ 27.4$ billion)(0.35), or $\$ 9.6$ billion. ${ }^{37}$ This upper bound for the impact of 863(b) contrasts with an official estimate of $\$ 1.4$ billion as the 1996 revenue cost of the $863(\mathrm{~b})$ provision. Of course, not all firms that allocate export income against foreign source are able to benefit from this allocation, either because they have net operating losses for tax purposes and are therefore effectively exempt from taxation, or because they have deficit foreign tax credits. ${ }^{38,39}$

While $\$ 9.6$ billion represents an upper bound on the 1996 expenditure associated with $863(\mathrm{~b})$, it is also possible to establish a lower bound on 863(b) expenditures. Firms electing to allocate income to foreign source under 863(b) rather than use an FSC must anticipate greater benefits from the former than from the latter. Consequently, it is possible to infer a lower bound to the benefits that exporters anticipated from the export source rules in 1996 by calculating the tax savings available by using FSCs rather than 863(b). FSCs offer the prospect of excluding at least 15

37 This calculation is based on the U.S. statutory corporate income tax rate of 35 percent. It is important to note that, in 1996 , taxpayers claimed $\$ 10.0$ billion of "definitely allocable deductions" against their gross 863 (b) income of $\$ 27.4$ billion, making a net 863 (b) income of $\$ 17.5$ billion. Unfortunately, the ambiguous nature of these deductions-specifically, what it is that taxpayers do, and think that they should, include among such deductionsmakes it very difficult to know the extent to which it is appropriate to reduce gross $863(\mathrm{~b})$ income in calculating the net tax benefit. We are grateful to various U.S. Treasury and IRS officials in drawing attention to the problem of identifying the magnitude of actual net 863 (b) income. In calculating the upper bound on 863 (b) tax benefits, we do not consider reported definitely allocable deductions.

38 There is a separate issue that features prominently in government calculations but that is unlikely to change the interpretation of the calculations that follow. Allocations of income against foreign source using Section 863(b) typically triggers an automatic allocation of various expenses (such as interest charges and $R \& D$ expenses) likewise against foreign source. This expense allocation does not affect the tax liabilities of taxpayers with deficit foreign tax credits, but will modestly affect the tax liabilities of taxpayers with excess foreign tax credits.

39 In the absence of perfect knowledge of what firms would do without the 863(b) provisions, any calculation of their revenue impact is subject to error. Putting aside the quantitatively unimportant issue of exporters with excess foreign tax credits who use 863(b) but have net operating loss carryforwards, the main issue concerns the extent to which firms benefit from 863 (b) allocations due to their foreign-tax-credit status situations. Applying the findings of Grubert, Randolph, and Rousslang (1996), who report that, in 1992, 35 percent of foreign income is received by American multinational firms with excess foreign tax credits, it follows that the $\$ 9.6$ billion figure might be reduced by 65 percent, to roughly $\$ 3.4$ billion. Of course, even this simple calculation is likely to understate the actual revenue effect of $863(\mathrm{~b})$, since exporters with excess foreign tax credits are more likely to use 863(b) allocations than are others, and Grubert, Randolph, and Rousslang's 35-percent figure is calculated after 863(b) allocations are performed. 
percent of export income from the domestic tax base; moreover, exporters can simultaneously allocate half of export profits through $863(\mathrm{~b}){ }^{40}$ Hence, this alternative implies that the value of $863(\mathrm{~b})$ allocations for firms that use 863(b) exclusively must equal or exceed the available FSC benefit plus half the $863(\mathrm{~b})$ benefit. It follows that the 863(b) allocation when used exclusively must be worth at least double the FSC benefit of excluding 15 percent of export profits from taxable income.

Since gross $863(\mathrm{~b})$ income in 1996 equals $\$ 27.4$ billion, it follows that this income corresponds to the allocation of $\$ 54.8$ billion of export profit. If those export profits were instead routed entirely through FSCs using the 23-percent allocation method, they would generate $(\$ 54.8)(0.15)(0.35)=$ $\$ 2.9$ billion of U.S. tax saving from the FSC exclusion. By the previous reasoning, the value of the $\$ 54.8$ billion of $863(\mathrm{~b})$ income must be at least twice $\$ 2.9$ billion, or $\$ 5.8$ billion, which exceeds four times the government's estimates.

This calculation is subject to three important limitations. The first is that not all exports are eligible for FSC treatment, so the lower bound on the value of section 863(b) benefits should exclude export income for FSC-ineligible items. Restricting attention just to manufacturing industries, a subset of FSC-eligible export property, yields $\$ 18.2$ billion of section $863(\mathrm{~b})$ income and implied export profits of $\$ 36.4$ billion. This, in turn, would generate $\$ 1.9$ billion of tax saving if routed instead through FSCs, so this $863(\mathrm{~b})$ income must have been anticipated to generate tax savings of at least $\$ 3.8$ billion, which is almost three times the government's estimate.

The second limitation is that many taxpayers using FSCs elect to allocate half their export income through $863(\mathrm{~b})$ as a matter of course, even though the $863(\mathrm{~b})$ treatment might be of little value because they have deficit foreign tax credits for the foreseeable future. In practice, the magnitude of $863(\mathrm{~b})$ income is such that, even if all FSC transactions generated such $863(\mathrm{~b})$ income, there nonetheless would have to exist taxpayers who use the 863(b) allocation method exclusively. In order to estimate the magnitude of this income, it is necessary to infer total export profits run through FSCs by inverting the reported FSC manufacturing net exempt income of $\$ 7.4$ billion, which corresponds to $\$ 49.1$ billion $[(\$ 7.4$ billion $) /(0.15)]$ of export profit. If all taxpayers using FSCs also allocated half of export profits (the maximum to which they are

40 Taxpayers have several options other than the 23-percent combined-taxable-income method of determining FSC income, any of which can provide greater than 15-percent exclusion of export income. Table 4 offers suggestive but inconclusive evidence of the use
of these alternatives. 
entitled) through 863(b), then $\$ 24.6$ billion of $863(\mathrm{~b})$ income would represent allocations by firms running their exports through FSCs. ${ }^{41}$

In order to determine an extreme lower bound on the export subsidy through 863(b), suppose that firms using FSCs and simultaneously allocating half of export profits through 863(b) consider the 863(b) allocation to have zero value. For the purpose of calculating $863(\mathrm{~b})$ benefits, suppose also that only manufactured exports can receive FSC treatment. Since manufacturing export profits allocated via section 863(b) equal $\$ 36.4$ billion, it follows that a minimum of $\$ 11.8$ billion (the difference between $\$ 36.4$ billion and $\$ 24.6$ billion) of export profits were allocated through 863(b) without using FSCs. These taxpayers had the option of simultaneously running their exports through an FSC and allocating half of export profits via $863(\mathrm{~b})$, and chose not to do so. Using the same methodology as above, this implies that the value of the 863(b) treatment of these $\$ 11.8$ billion of export profits exceeds the value of running corresponding exports through an FSC, or $\$ 1.24$ billion. ${ }^{42}$ Thus, an extreme lower bound of the value of $863(\mathrm{~b})$ elections for 1996 , based on restricting FSCs to manufacturing only, assuming that taxpayers splitting income between FSCs and 863(b) obtain no value from the latter, and assigning taxpayers with $863(\mathrm{~b})$ allocations the benefits they would have received had they chosen FSCs instead, is only 11 percent below the value reported by the U.S. federal government. ${ }^{43}$

41 Note that this calculation ignores the "marginal costing" option that taxpayers can use to overstate FSC income. Since "marginal costing" is not an option in allocating 863(b) income, the calculation therefore overstates the amount of aggregate 863(b) income derived from FSC use and understates the total value of $863(\mathrm{~b})$ allocations.

42 This figure is derived as $(\$ 11.8$ billion $)(2)(0.15)(0.35)=\$ 1.24$ billion.

43 This calculation is predicated on a certain degree of rationality on the part of taxpayers. Naturally, even rational taxpayers can make planning mistakes, only to find afterward that other choices would have led to more beneficial tax outcomes. From the standpoint of export incentives, however, what matters is what taxpayers believe at the time they decide to export goods from the United States. Since exporters are aware of their FSC options, those who choose not to exercise them in favor of 863(b) must believe that they have available a more attractive alternative-whatever their ultimate tax situation may be at year's end. There is a separate issue concerning "definitely allocable deductions" against 863(b) income. It is not clear whether reported "definitely allocable deductions" actually represent expense items that are appropriate to deduct from $863(\mathrm{~b})$ income-or if such expenses would be deductible from FSC income if taxpayers chose to route exports through FSCs instead. Even granting full FSC deductibility to "definitely allocable deductions" changes the lower-bound calculation minimally. According to unpublished IRS statistics, manufacturing exporters claimed $\$ 4.9$ billion of "definitely allocable deductions" against $\$ 18.2$ billion of $863(\mathrm{~b})$ income in 1996. Hence, "definitely allocable deductions" represent 27 percent of gross $863(\mathrm{~b})$ income in manufacturing that year. By this reasoning, the $\$ 11.8$ billion of gross export profits allocated strictly through $863(\mathrm{~b})$ corresponds to $\$ 8.6$ billion (73 percent of $\$ 11.8$ billion) of net 863 (b) income. The extreme lower bound of the 
The third limitation is that the starting point of these calculations is information gleaned from corporate tax returns together with the official revenue figures published by the federal government. Inaccuracies in this information will lead to erroneous conclusions. If, for example, the federal government underestimates the revenue effect of FSCs, then the preceding calculation will generate too high a lower bound of the value of 863(b) allocations. The general point is that the existence of an FSC alternative implies a lower bound to the value that taxpayers must anticipate receiving from $863(\mathrm{~b})$, and this lower bound exceeds official estimates of the 863(b) tax saving. Since export incentives are functions of what taxpayers think they receive in return, it follows that total export incentives exceed official estimates. Finally, these calculations omit consideration of other export subsidies, such as the foreign-source treatment of 100 percent of the income of domestically-located foreign sales subsidiaries, for which no public information is available.

Having established the relevant bounds for the tax expenditures associated with $863(\mathrm{~b})$, a conservative, central estimate can be derived by assuming that one-half of all exports using FSCs jointly use $863(\mathrm{~b})$ and that these $863(\mathrm{~b})$ allocations are not valuable to exporters. The value of the remaining $863(\mathrm{~b})$ allocation is established by doubling the FSCequivalent incentive as described above, yielding a tax-expenditure estimate of $\$ 2.8$ billion for the $863(\mathrm{~b})$ subsidy in $1996 .{ }^{44}$ Combining this figure with a $\$ 3.0$ billion estimate for FSC tax expenditures, ${ }^{45}$ it follows that the 1996 ratio of total export tax subsidies to total U.S. goods exports is $\$ 5.8$ billion $/ \$ 612$ billion, or roughly 1 percent. In this sense, the export subsidies provided through the income tax are equivalent to a 1-percent ad valorem subsidy.

\subsection{Previous Estimates of the Effect of Export Incentives}

There is extensive interest in the effect of U.S. export incentives on the behavior of American multinational firms. The U.S. Department of the value of $863(\mathrm{~b})$ elections for 1996 then becomes $\$ 905$ million [which equals $\$ 8.6$ bil-
lion)(2)(0.15)(0.35)].

44 This calculation begins with total net exempt income of $\$ 8.5$ billion for FSCs in 1996. If half of these profits are allocated to foreign source through $863(\mathrm{~b})$ without providing associated tax benefits, then $\$ 28.3$ billion ( $\$ 4.2$ billion/0.15) of the $\$ 54.8$ billion of $863(\mathrm{~b})$ export-related profits should not be considered in calculating the tax consequences of $863(\mathrm{~b})$. The remaining $\$ 26.5$ billion of export profits translates into estimated expenditures of $\$ 2.8$ billion as follows: $(\$ 26.5$ billion $)(2)(0.15)(0.35)=\$ 2.78$ billion.

45 This figure corresponds to $\$ 8.5$ billion of net exempt income multiplied by the tax rate of $35 \%$. It differs from the numbers provided in Figure 5 due to the lag between budget estimates of tax expenditures and the publication of the 1996 FSC report. 
Treasury produces periodic estimates of the effect of the FSC and 863(b) provisions on the volume of U.S. exports. These estimates are based on a standard trade model that employs assumptions on the elasticity of U.S. supply and elasticity of foreign demand for U.S. exports to derive the direct effects of the subsidies along with the indirect effects created by changes in the exchange rate. Employing these methodologies, the U.S. Treasury $(1993,1997)$ estimates that repeal of FSC provisions would have resulted in the loss of $\$ 1.5$ billion in goods exports in 1992 and that the repeal of the sales-source rules would have resulted in the loss of $\$ 2.1$ billion in goods exports in 1990 . In these reports, the impact of exchange-rate changes on imports mitigates the overall impact of the subsidies on the trade balance.

Horst and Pugel (1977) analyze the likely incidence and allocative effects of the DISC program in place in the mid-1970s. Based on a set of assumed demand elasticities and pricing behavior of American exporters, they conclude that the tax savings from DISCs are likely to be threequarters reflected in lower export prices, and one-quarter reflected in greater after-tax profits of American companies. They conclude, on the basis of these estimates, that the DISC program increased U.S. exports by $\$ 2.1$ billion in 1974, a figure significantly lower than the U.S. Treasury estimate of $\$ 4.7$ billion.

Mutti and Grubert (1984) create a general equilibrium model to study the welfare consequences of the DISC program. In this model, Mutti and Grubert capture the direct effects on exporting behavior along with the welfare consequences of capital reallocations on three factors of production--skilled labor, unskilled labor, and capital. Employing parameter values estimated from DISCs in 1979, the general equilibrium model suggests that removal of the DISC program would have resulted in a 3.1percent decline in exports and a welfare benefit of half the tax cost of the DISC program.

Rousslang and Tokarick (1994) estimate that the FSC and sales-source rules together have the same effect on trade volume as would reducing American tariffs by more than one-third. This study illustrates the ambiguity of the welfare effects of export tax incentives, due to terms-of-trade effects that serve to counteract the effect of preexisting tariffs.

Kemsley (1998) explores the effect of 863(b) on a firm's choice between offshore production and domestic exporting. Kemsley's study differs from much of this literature by examining the responses of actual firms to changing tax incentives. Kemsley analyzes a pooled cross-section of American multinational firms from 1984 to 1992, finding that firms with contemporaneous excess tax credits have higher 
ratios of exports to sales by foreign affiliates than do other firms. Since exporting from the United States and selling locally by foreign affiliates represent two substitute means of serving foreign markets, it follows from Kemsley's results that the availability of excess foreign tax credits encourages American firms to export, though he does not test the proposition directly.

\section{EVIDENCE OF THE EFFECT OF EXPORT INCENTIVES}

This section considers three types of evidence of the market effect of U.S. export incentives. The first is the export impact of the 1984 DISC repeal and transition to FSCs. The second is the impact on the U.S. dollar of events surrounding the 1997 European complaint against the United States before the WTO. The third is U.S. stock market reactions to the 1997 WTO event. The results all indicate that U.S. export incentives have important effects on the behavior of American exporters.

\subsection{The Impact of the 1984 DISC Repeal on U.S. Export Performance}

As suggested by the aggregate evidence provided in Section 4.1, the 1984 repeal of the DISC provisions and their replacement with FSC provisions appears to have had a large impact on the usage of these entities. While FSCs were designed to offer roughly the same tax subsidies as those available with the prior DISC program, the use of FSCs is more cumbersome in view of the need to create a new offshore entity meeting various requirements. Thus, the transition to the FSC regime may have prevented exporters, particularly small exporters, from realizing the benefits of the export subsidies.

The regressions reported in Table 7 explore the link between the transition from DISCs to FSCs and subsequent export performance. The dependent variables in these regressions are export growth rates of two- and (non-overlapping) three-digit SIC industry segments within manufacturing. In the specifications reported in columns (1) and (2), the dependent variable is the percentage change in exports from 1984 to 1985. The mean and median of the dependent variable are -3.14 and -3.84 percent, respectively. ${ }^{46}$ Average exports per DISC in 1983 are used to proxy for average exporter size within industry segments, while

46 The dollar value of all U.S. exports dropped by 2.4 percent from 1984 to 1985 , and overall manufacturing exports increased by only 1.4 percent. 
TABLE 7

The Effect of the 1984 DISC Repeal on U.S. Export Performance

Panel A: Regression Results

Change in U.S. exports (\%)

\begin{tabular}{lcccc} 
& $(1)$ & $(2)$ & $(3)$ & $(4)$ \\
Parameter & $1984-1985$ & $1984-1985$ & $1984-1986$ & $1984-1986$ \\
\hline Constant & -0.0823 & -0.0211 & -0.0440 & 0.0092 \\
& $(0.0161)$ & $(0.0333)$ & $(0.0282)$ & $(0.0456)$ \\
Average exports per & 0.0032 & 0.0041 & 0.0029 & 0.0037 \\
DISC, 1983 & $(0.0005)$ & $(0.0004)$ & $(0.0010)$ & $(0.0012)$ \\
DISC share of U.S. & & -0.1434 & & -0.1247 \\
exports, 1983 & & $(0.0686)$ & & $(0.1053)$ \\
$R^{2}$ & 0.4594 & 0.5663 & 0.1842 & 0.2234 \\
Number of observations & 29 & 29 & 29 & 29
\end{tabular}

Panel B: Descriptive Statistics

Number of observations

Mean

Median

Standard

$\%$ change in U.S. exports: 1984-1985

1984-1986

29

29

$-0.0314$

$-0.0384$

0.0951

9

0.0023

0.0151

0.1368

Average exports per

DISC, 1983

29

15.7866

9.8800

20.0124

DISC share of U.S.

exports, 1983

29

0.5188

0.5308

0.2466

Note: The dependent variable in columns (1) and (2) of Panel A is the percentage change in U.S. exports from 1984 to 1985 by industry sector. The dependent variable in columns (3) and (4) of Panel $A$ is the percentage change in U.S. exports from 1984 to 1986 by industry sector. "Average exports per DISC, $1983^{\prime \prime}$ is an industry's ratio of export gross receipts (in \$million) for all DISCs to the number of DISC returns in 1983. "DISC share of U.S. exports, 1983" is an industry's ratio of export gross receipts for all DISCs to total exports in 1983. Observations correspond to (non-overlapping) two-digit and three-digit manufacturing industry segments. Heteroskedasticity-consistent standard errors are in parentheses. Descriptive statistics are provided in Panel B. 
the importance of DISCs to an industry is captured by the share of exports routed through DISCs in 1983.47

As column (2) illustrates, exports of manufacturing industries characterized by smaller average exporter size and higher initial use of DISCs grew more slowly in the year following repeal of the DISC provisions. This specification suggests that an increase of 1 percent in the DISC share of industry exports corresponds to 0.14-percent-slower export growth between 1984 and 1985. This relationship can then be extrapolated in order to estimate the effect of DISC repeal on total manufacturing exports, based on the insight that firms not using DISCs in 1984 would not be adversely affected by their discontinuance. Since DISCs accounted for 65.8 percent of manufacturing exports in 1983, it follows that the 1984 change reduced an average industry's exports by 9.2 percent (the product of 65.8 and 0.14 percent) compared to a hypothetical industry that never uses DISCs.

In order to calculate the net effect of DISC repeal on total U.S. manufacturing exports, it is necessary to incorporate the response of the exchange rate, since long-run trade balance requires dollar weakening to compensate for reduced export subsidies. The impact of induced exchange-rate changes is not captured in the estimated coefficient 0.14 , since this coefficient is identified by differences between industries in their DISC usage prior to 1985, while all ind ustries face the same exchange rate. Taking the aggregate price elasticity of U.S. exports to be roughly equal to -1.0 , and the aggregate price elasticity of U.S. imports to be roughly equal to $-0.5,48$ it follows that the exchange-rate response significantly mitigates the export effect of DISC removal. ${ }^{49}$ This calculation implies that the 1984 policy change was responsible for a 3.1-percent decline in U.S. manufacturing exports.

Table 7 also reports significant coefficients on average sizes of DISC exporters, suggesting that the repeal of DISC legislation was particularly

47 Although 1982 legislation limited the attractiveness of DISCs, DISC usage did not abate significantly by 1983 . The results reported in Table 7 are robust to using data on average exporter size and share of exports in 1980. To the degree that some exporters used multiple DISCs, the average-size variable would be improperly measured. Evidence provided in Table 5 suggests, however, that-at least in the case of FSCs-it is uncommon for single exporters to use several export entities.

48 Sawyer and Sprinkle (1996) suggest these estimates on the basis of their survey of empirical studies of aggregate U.S. export and import elasticities. See also Hooper, Johnson, and Marquez (1998).

49 Based on these estimates, and starting from trade balance, DISC repeal reduces exports by $9.4+e$ percent and reduces imports by $-0.5 e$ percent, in which $e$ is the change in the dollar exchange rate. Trade balance then implies that $e=-6.3$, and the resulting change in exports is 3.1 percent. 
costly to smaller exporters. Evaluating the coefficient reported in column (2) at mean exports per DISC implies that doubling the average size of exporters in an industry is associated with 6.5-percent-faster industry export growth between 1984 and 1985. Columns (3) and (4) report similar results for export performance over the 1984-1986 period. The estimated coefficients in these regressions are less significant than are those for the regressions reported in columns (1) and (2), reflecting the growing importance over time of omitted variables.

The repeal of the DISC provisions and the transition to the FSC/ICDISC regime represented an effort on the part of the United States to provide a similar export subsidy through a different vehicle. The regressions described in Table 7 suggest that these changes, while largely formal rather than substantive, nonetheless worsened U.S. export performance. As events transpired, the adverse consequences of DISC repeal were attenuated by the subsequent 1986 U.S. tax rate reduction, which increased the numbers of exporters with excess foreign tax credits and thereby heightened the value and importance of $863(\mathrm{~b})$ allocations.

\subsection{Export Subsidies and Exchange Rates ${ }^{50}$}

U.S. tax policies encourage exports by improving the after-tax margins received by American exporters. As a result, the introduction of an export subsidy typically makes exporters eager to expand their sales abroad, which in competitive markets results in reduced purchase prices for foreign buyers and greater export volume. ${ }^{51}$ Long-run trade balance then implies that the prices of American goods must appreciate relative to the prices of foreign goods, since otherwise the United States would become a net exporter. This price adjustment can be accomplished either by greater inflation differentials between the United States and other countries, or, more likely, by an appreciation of the value of the American dollar relative to the values of foreign currencies. One simple way to think about how this happens is to note that the export subsidy makes American goods more attractive to foreign buyers, which leads to dollar appreciation. The endogenous change in the value of the dollar in turn serves to attenuate the effect of the export subsidy on export volumes, since American goods become less attractive to foreign buyers as the dollar appreciates. The net effect of the subsidy and the endogenous

50 This section draws on Desai and Hines (2001).

51 The situation is somewhat more complex when firms export to their own foreign affiliates, since then the existence of export subsidies encourages exporters to charge higher export prices. This incentive conflicts with regulations that require firms to charge arm'slength prices for exports to related parties, so the net effect on final prices is unclear. See Rangan and Lawrence (1993) and Clausing (2001). 
change in the value of the dollar is to expand the volumes of both American exports and American imports. These expansions are of course nonuniform, and in particular, exports of goods that are ineligible for the tax subsidy will fall, even as exports of those that are eligible for the tax subsidy will rise.

This section considers evidence of the impact of the FSC program on the value of the American dollar relative to the values of foreign currencies. Over the course of November 1997-April 2000 there were several twists and turns in the negotiations between the United States and the World Trade Organization over the likelihood of the retention of American export subsidies. By looking at changes in the value of the American dollar on those dates, it is possible to infer the effect of the FSC program on proclivities to export from the United States. Since many other factors also influence exchange rates, it is necessary to interpret this information carefully.

The leftmost column of Table 8 identifies the dates of major events surrounding the FSC controversy between the United States and the WTO. Of these, two are prominent: November 18, 1997, when the EU complaint was first lodged with the WTO, and July 23, 1999, when the WTO's Dispute Resolution Panel issued its interim report stating that the American FSC program violated WTO rules. The July 23 report also indicated that the United States would be required to rescind its FSC provisions by October 1, 2000. Contemporaneous press accounts indicate that both November 18, 1997 and July 23, 1999 were considered momentous dates in the history of the trade dispute; other dates are significant to differing degrees.

A simple way to identify the impact of the events surrounding the WTO controversy is to regress daily changes in the value of the U.S. dollar against dummy variables for event dates, controlling for other observable factors. Table 8 presents estimated coefficients from such regressions. The sample for these regressions consists of foreign exchange trading days between January 1, 1997 and June 13, 2000. The dependent variable is the daily percentage change in the value of the American dollar relative to the British pound sterling. ${ }^{52}$ Since the dependent variable is calculated as the percentage change in numbers of pounds to the dollar, it follows that a negative value of the dependent variable corresponds to dollar weakening. Exchange rates are calculated as of market closing in New York, so prices will reflect any impact of European news on the same days.

52 The British pound is chosen as the alternative to the U.S. dollar for these calculations because it is a common benchmark currency, and one that was not buffeted either by events surrounding the European Monetary Union or the economic crises in Japan and
Asia. 
TABLE 8

Exchange-Rate Responses to WTO Events ${ }^{a}$

\begin{tabular}{|c|c|c|c|c|}
\hline & (1) & (2) & (3) & (4) \\
\hline Constant & $\begin{array}{c}-0.0094 \\
(0.0165)\end{array}$ & $\begin{array}{c}0.0099 \\
(0.0169)\end{array}$ & $\begin{array}{c}0.0093 \\
(0.0165)\end{array}$ & $\begin{array}{c}0.0099 \\
(0.0169)\end{array}$ \\
\hline $\begin{array}{l}\text { November } 18,1997 \\
\text { Charges Filed }(-)\end{array}$ & $\begin{array}{c}-0.1092 \\
(0.0165)\end{array}$ & $\begin{array}{r}-0.1076 \\
(0.0181)\end{array}$ & $\begin{array}{c}-0.1099 \\
(0.0170)\end{array}$ & $\begin{array}{l}-0.1080 \\
(0.0186)\end{array}$ \\
\hline $\begin{array}{l}\text { December } 17,1997 \\
\text { Inconclusive consultations (-) }\end{array}$ & $\begin{array}{c}-0.7160 \\
(0.0165)\end{array}$ & $\begin{array}{c}-0.7165 \\
(0.0174)\end{array}$ & $\begin{array}{c}-0.7101 \\
(0.0332)\end{array}$ & $\begin{array}{c}-0.7128 \\
(0.0376)\end{array}$ \\
\hline $\begin{array}{l}\text { February } 10,1998 \\
\text { Inconclusive consultations (-) }\end{array}$ & $\begin{array}{c}-0.5695 \\
(0.0165)\end{array}$ & $\begin{array}{c}-0.5732 \\
(0.0180)\end{array}$ & $\begin{array}{c}-0.5758 \\
(0.0175)\end{array}$ & $\begin{array}{c}-0.5738 \\
(0.0188)\end{array}$ \\
\hline $\begin{array}{l}\text { July } 23,1999 \\
\text { Interim report issued (-) }\end{array}$ & $\begin{array}{c}-0.3004 \\
(0.0165)\end{array}$ & $\begin{array}{c}-0.3070 \\
(0.0217)\end{array}$ & $\begin{array}{c}-0.3018 \\
(0.0183)\end{array}$ & $\begin{array}{c}-0.3078 \\
(0.0227)\end{array}$ \\
\hline $\begin{array}{l}\text { August 6, } 1999 \\
\text { Joint review request (+) }\end{array}$ & $\begin{array}{c}0.1050 \\
(0.0165)\end{array}$ & $\begin{array}{c}0.1117 \\
(0.0255)\end{array}$ & $\begin{array}{c}0.1028 \\
(0.0205)\end{array}$ & $\begin{array}{c}0.1103 \\
(0.0290)\end{array}$ \\
\hline $\begin{array}{l}\text { September } 17,1999 \\
\text { WTO ruling }(-)\end{array}$ & $\begin{array}{c}-0.0078 \\
(0.0165)\end{array}$ & $\begin{array}{c}-0.0130 \\
(0.0196)\end{array}$ & $\begin{array}{c}0.0054 \\
(0.0209)\end{array}$ & $\begin{array}{r}-0.0115 \\
(0.0241)\end{array}$ \\
\hline $\begin{array}{l}\text { October 28, } 1999 \\
\text { American appeal (+) }\end{array}$ & $\begin{array}{c}0.3342 \\
(0.0165)\end{array}$ & $\begin{array}{c}0.3239 \\
(0.0282)\end{array}$ & $\begin{array}{c}0.3362 \\
(0.0197)\end{array}$ & $\begin{array}{c}0.3252 \\
(0.0310)\end{array}$ \\
\hline $\begin{array}{l}\text { November 2, } 1999 \\
\text { Appeal withdrawal (-) }\end{array}$ & $\begin{array}{c}-0.3922 \\
(0.0165)\end{array}$ & $\begin{array}{r}-0.3930 \\
(0.0168)\end{array}$ & $\begin{array}{c}-0.3921 \\
(0.0165)\end{array}$ & $\begin{array}{c}-0.3929 \\
(0.0169)\end{array}$ \\
\hline $\begin{array}{l}\text { February } 24,2000 \\
\text { Final ruling }(-)\end{array}$ & $\begin{array}{c}0.4503 \\
(0.0165)\end{array}$ & $\begin{array}{c}0.4476 \\
(0.0173)\end{array}$ & $\begin{array}{c}0.4504 \\
(0.0165)\end{array}$ & $\begin{array}{c}0.4477 \\
(0.0173)\end{array}$ \\
\hline $\begin{array}{l}\text { February } 28,2000 \\
\text { Summers rebuttal (+) }\end{array}$ & $\begin{array}{c}0.4981 \\
(0.0165)\end{array}$ & $\begin{array}{c}0.4831 \\
(0.0381)\end{array}$ & $\begin{array}{c}0.4918 \\
(0.0389)\end{array}$ & $\begin{array}{c}0.4793 \\
(0.0503)\end{array}$ \\
\hline $\begin{array}{l}\text { April 7, } 2000 \\
\text { Formal American response (+) }\end{array}$ & $\begin{array}{c}0.1320 \\
(0.0165)\end{array}$ & $\begin{array}{c}0.1360 \\
(0.0210)\end{array}$ & $\begin{array}{c}0.1328 \\
(0.0171)\end{array}$ & $\begin{array}{c}0.1365 \\
(0.0214)\end{array}$ \\
\hline $\begin{array}{l}\% \text { change [S\&P } 500 \text { (US) } \\
\text {-FTSE } 100 \text { index (UK)] }\end{array}$ & & $\begin{array}{c}0.5398 \\
(1.3269)\end{array}$ & & $\begin{array}{c}0.5372 \\
(1.3295)\end{array}$ \\
\hline $\begin{array}{l}\text { Change (US-UK interest- } \\
\text { rate difference) }\end{array}$ & & & $\begin{array}{c}-0.0374 \\
(0.2068)\end{array}$ & $\begin{array}{c}-0.0230 \\
(0.2106)\end{array}$ \\
\hline $\begin{array}{l}R^{2} \\
\text { Number of observations }\end{array}$ & $\begin{array}{c}0.0090 \\
840\end{array}$ & $\begin{array}{l}0.0096 \\
810\end{array}$ & $\begin{array}{l}0.0091 \\
840\end{array}$ & $\begin{array}{l}0.0096 \\
810\end{array}$ \\
\hline
\end{tabular}

(a) Dependent variable: one-day percentage change in $\mathrm{f} / \$$ exchange rate. 
Note: The sample consists of observations of foreign exchange trading days between January 1, 1997 and June 13,2000. The columns report coefficients from OLS regressions in which the dependent variable equals the daily percentage change in the value of the American dollar relative to the British pound sterling. Since the dependent variable is calculated as the percentage change in numbers of pounds to the dollar, a negative value of the dependent variable corresponds to dollar weakening. The table reports estimated coefficients for dummy variables for each of the eleven event dates; expected signs are indicated in parentheses. "\% change [S\&P 500 (US) - FTSE 100 index (UK)]" is the daily difference in percentage performance of the S\&P 500 and FTSE 100 indices. "Change (US-UK interest-rate difference)" is the daily change in U.S. and British 90-day government interest rates. Heteroskedasticity-consistent standard errors are in parentheses.

The results reported in the first column of Table 8 indicate that the dollar weakened on November 18, 1997, falling by 0.1092 percent against the pound sterling. This decline is statistically significant and quite consistent with the predicted effect of removing U.S. export subsidies, since doing so shifts the supply schedule for American exports. Of course, the foreign exchange market could not be confident, on the basis of the November 18, 1997 action, that the United States would ultimately remove the FSC portion of its export tax subsidies. Nonetheless, it was known at the time that the United States was vulnerable to charges such as those brought by the European Union, since the FSC program was so similar to its ill-fated predecessor, the DISC program. All that was necessary was for a major complainant to appear with charges against the United States, and that happened on November 18, 1997.

Given uncertainty over the ultimate impact of any WTO action, an exchange-rate response of roughly 0.1 percent is quite in line with the effect of estimated supply and demand elasticities. At an average profit margin of 10 percent, a 15-percent tax exclusion reduces taxable income by 1.5 percent of sales. At a tax rate of 35 percent, this generates a tax saving of 0.5 percent of sales-which, given the 35-percent tax rate, produces approximately a 0.75 -percent reduction in prices at which exporters would be willing to offer goods for foreign sale. Of course, elimination of the FSC program would not necessarily entail elimination of export subsidies through Section 863(b) allocations, so not all the value of FSC is likely to be lost in the course of a successful dispute brought by the European Union.

It follows from the aggregate export and import price elasticities cited earlier that an offsetting exchange-rate movement of two-thirds the size of the lost export subsidy-or 0.5 percent-is required to restore trade balance. ${ }^{53}$ Then allowing for the incomplete use of FSCs, and the backstop use of $863(\mathrm{~b})$ allocations by firms currently electing

53 Starting from trade balance, loss of FSC benefits reduces exports by $0.75+e$ percent and reduces imports by $-0.5 e$ percent, in which, $e$ is the change in the dollar exchange rate. Trade balance then implies that $e=-0.5$. 
FSC treatment of their exports, reduces this predicted effect, as does uncertainty over the final disposition of the FSC program. So the likely impact of the European Union action is to reduce the value of the dollar by perhaps 0.1 percent, which appears to be what happened on November 18, 1997.

Subsequent events in the WTO controversy are also associated with changes in the value of the dollar, though these events are likely to be less important from the standpoint of their direct impact on dollar values. As reported in column (1) of Table 8, the failure of initial consultations between the United States and the European Union on December 17,1997 is associated with a fall of 0.7160 percent of dollar value, though other major new items of the day no doubt contributed to the dollar's fall in value. Most other event dates are associated with dollar movements whose signs are consistent with the impact of FSC removal on foreignexchange values, though the magnitudes of the estimated coefficients are significantly greater than what might be expected from FSC removal alone. Thus the failed second consultations between the European Union and the United States on February 10, 1998 were associated with a 0.5695 -percent drop in the value of the dollar, and the (largely anticipated) July 23, 1999 interim report of the Dispute Resolution Panel with a 0.3004 -percent drop. The attempted reconciliation of the United States and the European Union on August 6, 1999 is associated with a 0.1050percent strengthening of the dollar, while the (anticipated) September 17, 1999 WTO ruling against the United States is associated with a 0.0078-percent weakening. The American appeal on October 28, 1999 coincides with an appreciation of 0.3342 percent of the dollar's value, and the withdrawal of this appeal on November 2, 1999 coincides with a depreciation of 0.3922 percent.

The only anomalous sign appears on February 24, 2000, when the fully anticipated WTO final ruling against the United States is associated with a rise in the value of the dollar by 0.4503 percent. The aggressive February 28 response by U.S. Treasury Secretary Lawrence Summers is associated with a dollar appreciation of 0.4981 percent, and the formal American reply to the Dispute Resolution Board on April 7, 2000 is associated with an appreciation of 0.1320 percent.

Since many events in the course of a day are likely to influence exchange rates, and the expected impact of the FSC program is subtle, it is a mistake to overinterpret the results reported in column (1) of Table 8 . Columns (2)-(4) of the same table report estimated coefficients from regressions that add daily measures of changes in stock market indices and short-term interest rates. Specifically, the stock market variable is the daily difference in the performance (measured in percentage terms) 
of the U.S. S\&P 500 index and the British FTSE 100 index. The benefit of including such a variable in the regression is that stock market prices reflect the impact of omitted news variables, such as economic news, inflation fears, and various political developments that may be correlated with exchange-rate movements and therefore impart a correlation between exchange rates and equity prices. When included in the regression reported in column (2) of Table 8 , this variable takes the expected positive sign, while the absolute value of the coefficient on the dummy variable for November 18, 1997 falls slightly to 0.1076 . Column (3) introduces a variable equal to the difference in the daily change in U.S. and British short-term (90-day) government interest rates, which, when included, has little effect on daily event coefficients. The regression reported in column (4) of Table 8 includes both the stock index and interest-rate differences, with results that are similar to those reported in column (2).

While the results reported in Table 8 appear to be robust to the inclusion of additional explanatory variables that reflect the economic significance of daily events, it is inevitable that important factors are omitted. November 18, 1997 differs from most others in being a very slow news day, the main international-trade-related nuggets being the (anticipated) failure of a large Japanese bank and the lifting of the European ban on imports of Iranian pistachios. Hence, the filing of a European complaint against the United States was the major development, and it is reasonable to infer that the exchange-rate movement on that day reflects the impact of that news. While the consistency of the sign pattern for other event days, as reported in Table 8 , is reassuring, these coefficients reflect the cumulative effect of many factors unrelated to FSCs.

The November 18, 1997 evidence indicates that the market reaction to news of the European Union filing against the United States is consistent with other evidence of aggregate trade demand and supply elasticities, and with an expectation that the inability to use FSCs would affect American exports. Hence this evidence serves the function of offering a market-based test of previous conjectures as to the likely impact of FSCs on export patterns.

\subsection{Export Subsidies and Equity Prices}

It is useful to consider other indicators of the market's interpretation of events on November 18, 1997 in order to verify the role of the FSC controversy in influencing the value of the dollar on that day. Stock market valuations of publicly traded firms offer such indications, since, to the extent that the market believes the European Union complaint to have an effect on the American FSC program, the profitability of major 
American exporters is likely to be negatively affected. Correspondingly, the reaction of stock prices can be used to identify the incidence of these export subsidies.

The American stock market fell on November 18, 1997, but this in itself is inconclusive, since many factors influence stock prices. It is more instructive to contrast the performance of firms for which exports represent large fractions of their total sales with firms for which exports are relatively unimportant. In order to reduce the problems that inevitably accompany such comparisons, attention is restricted to firms reporting export sales, specifically Compustat firms continuously reporting their exports (which in some cases are zero) over the 1992-1998 period. This sample of 630 firms was divided into two groups, based on the fraction of total sales accounted for by exports from the United States, and divided at the median ratio of exports to total sales (approximately 11 percent). Within each group, stock price returns for November 18, 1997 were calculated, and within-group medians compared.

Figure 6 depicts this comparison. Firms for which export sales represented more than 11 percent of total sales in 1997 generally lost value on November 18, 1997, the median loss representing 0.7169 percent of the start-of-day stock value. Firms for which export sales represented less than 11 percent of total sales in 1997 also generally lost value on November 18, 1997, but these losses were considerably milder, the median loss representing just 0.2379 percent of the start-of-day stock value. This pattern is consistent with the value losses that would accompany the inability to benefit from FSCs in the future, and is all the more striking in light of the fact that a reduced value of the American dollar generally enhances the stock market prices (which are quoted in dollars) of major exporters. ${ }^{54}$

It is possible to take this analysis one step further, since even among firms with identical export exposures there is variation in the degree of share price sensitivity to future changes in tax subsidies for exports. In particular, firms with net operating loss (NOL) carryforwards do not pay current taxes, and have some chance of never doing so. To be sure, the existence of NOL carryforwards is an imperfect indicator of future tax sensitivity, but nonetheless one that is useful to consider.

Figure 7 depicts the stock price reactions on November 18, 1997 of firms with and without NOL carryforwards. The median firm with NOL carryforwards and a large fraction of sales from exports lost 0.674 percent of value on that day, while the median NOL firm with a small

54 See Desai and Hines (2000b) for a more detailed econometric evaluation of the evidence of differential stock price reactions on November 18, 1997. 


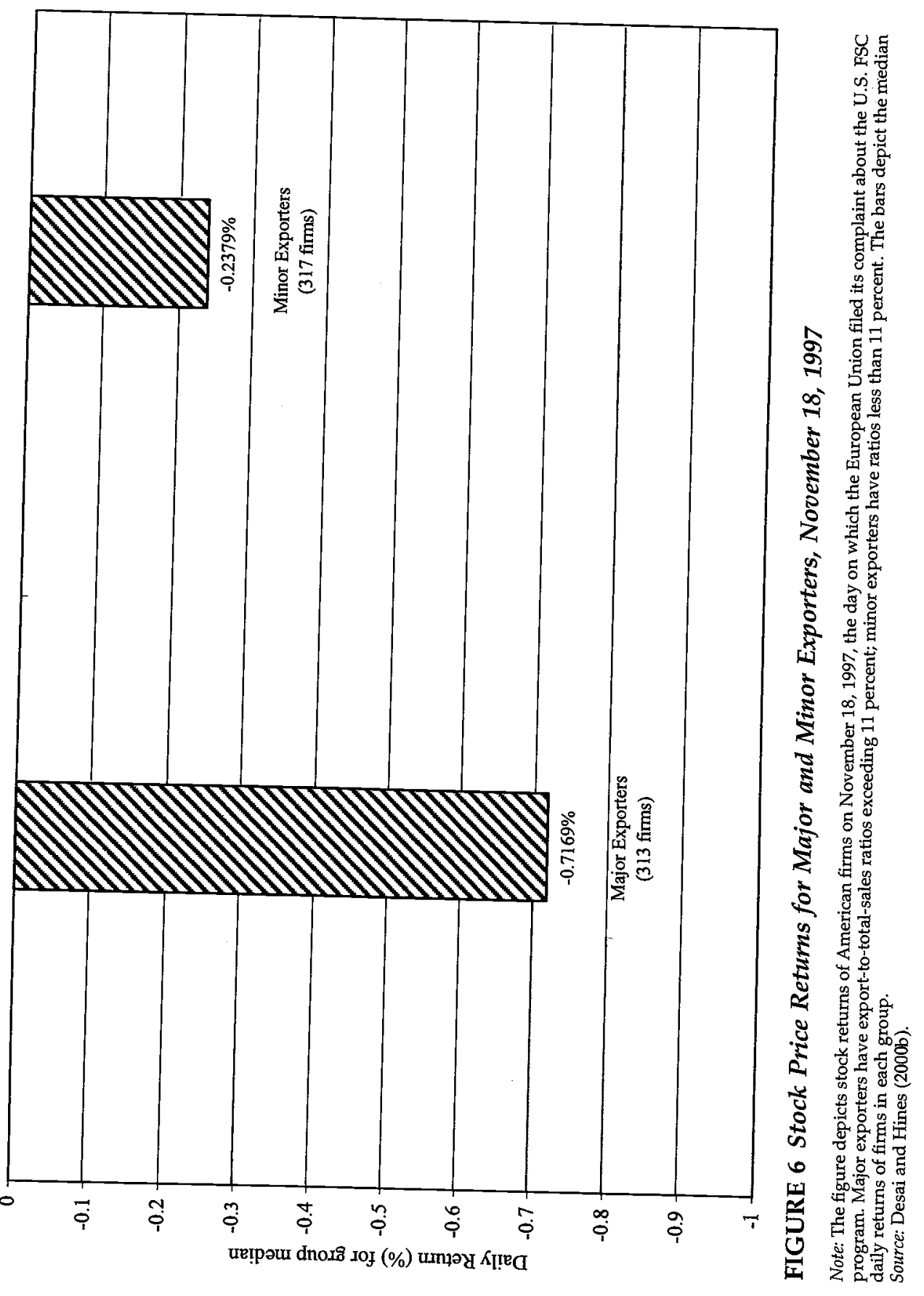




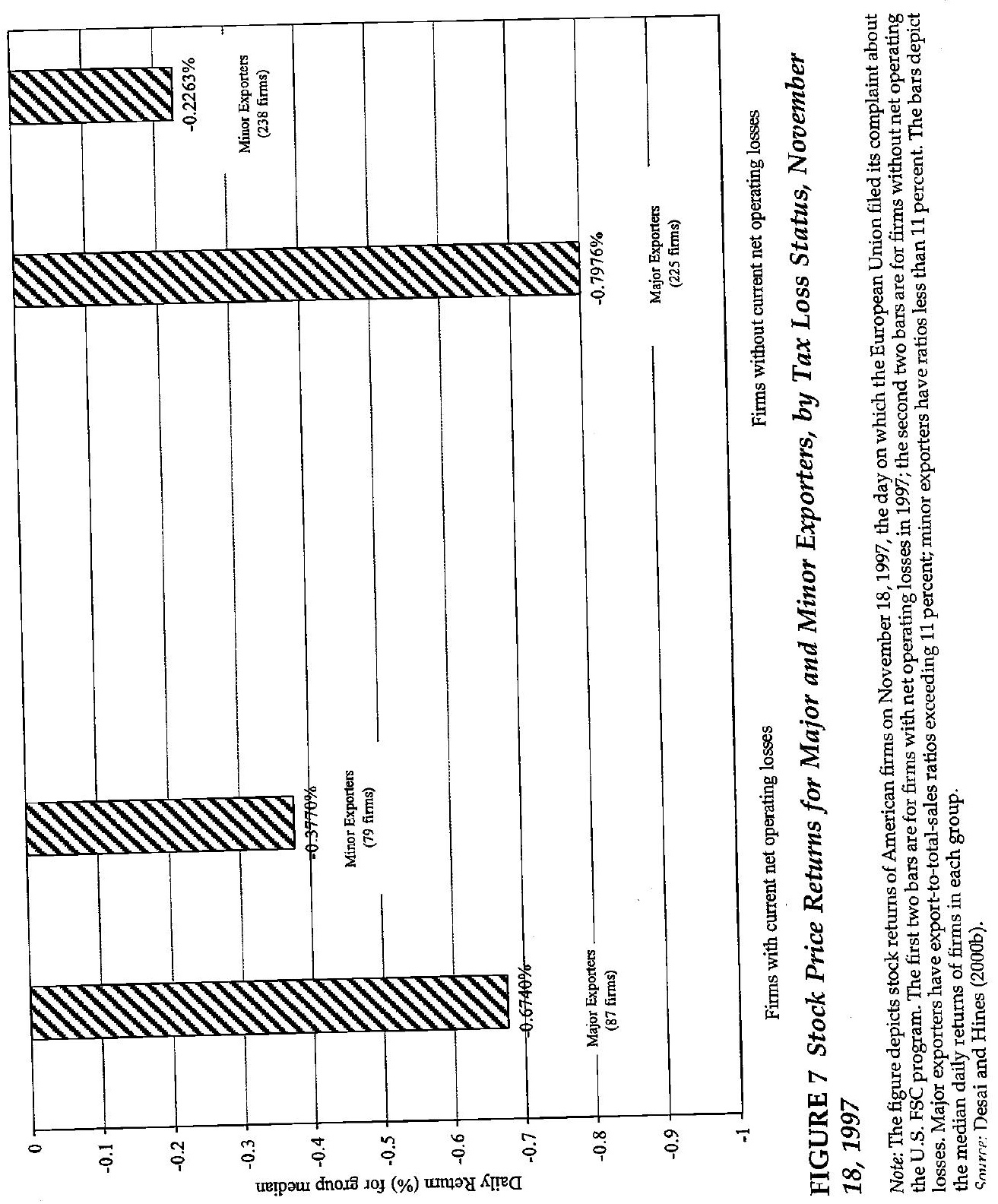


fraction of export sales lost 0.377 percent. The difference was considerably starker for firms without NOL carryforwards, where the median firm with a large fraction of export sales lost 0.7976 percent of value, while the median firm with a small fraction of export sales lost just 0.2263 percent of value. The pattern described in Figure 7 is quite consistent with expectations of future tax liabilities, since firms without NOL carryforwards are generally more tax-sensitive than those with NOL carryforwards. Furthermore, the difference between group median returns is generally consistent with differences in lost value as calculated from export fractions. ${ }^{55}$

\section{CONCLUSION}

The U.S. government provides sizable export incentives through the tax system. Because these tax subsidies are delivered in complicated ways, it can be difficult to assess their effects on behavior or even their overall magnitudes. What evidence is available suggests that the current, roughly $\$ 4$ billion a year, subsidy available from the use of FSCs is matched in magnitude by the subsidy associated with the allocation of export profits to foreign-source income. In combination, the exportrelated benefits available through the income tax translate to a 1-percent ad valorem equivalent export subsidy.

There is ample evidence that these export incentives influence the behavior of American taxpayers. Repeal of the DISC system in 1984, and its replacement with FSCs, is associated with significant changes in the patterns of American exports. This behavioral response suggests that the 1984 legislation did more than just replace one system with an identical alternative designed to meet GATT legal requirements. Event studies of market reactions to the WTO dispute similarly indicate the importance of these export subsidies. Foreign exchange markets reacted to the possibility of reduced American export subsidies, particularly as evidenced by the dollar's fall on November 18, 1997, the date on which Europe first filed its complaint with the WTO. The American stock market likewise reacted negatively to the WTO news on that date, with share prices of major American exporters falling in response to the possibility that their tax obligations might rise in the future.

Whatever one may think of the economic merits of providing export subsidies, it is clear that the American practice of embedding them

55 See Desai and Hines (2000b) for a detailed calculation. 
within the income tax system introduces several distortions compared to the simple ad valorem alternative. First, U.S. tax subsidies are not available for all categories of export goods, and administrative requirements make access costly for small exporters. Second, export incentives vary according to an exporter's profit rate and tax-loss carryforward situation. And third, an important class of export subsidy is available only to multinational firms with highly taxed foreign income. These considerations might be weighed against whatever advantages stem from complicating the workings of these subsidies and thereby obscuring them from casual inspection.

Multinational firms are responsible for most American exports, and these firms are subject to a very complicated array of tax rules providing what are often very curious incentives. The current trade dispute between the European Union and the United States draws close attention to the size and importance of foreign sales corporations, and may thereby result in a new and different kind of export subsidy through the tax system. One possibility is that FSCs might be replaced with a more uniform type of export incentive that would entail fewer economic distortions than the current system. Whatever the outcome of the current dispute, this is unlikely to be the last time that American policies are challenged by members of the World Trade Organization. And similarly, whatever system replaces the current FSC regime is not likely to be the final tax program to encourage American exports.

\section{REFERENCES}

Altshuler, Rosanne, and T. Scott Newlon (1993). "The Effects of U.S. Tax Policy on the Income Repatriation Patterns of U.S. Multinational Corporations." In Studies in International Taxation, Alberto Giovannini, R. Glenn Hubbard, and Joel Slemrod (eds.). Chicago: University of Chicago Press. Glenn Hubbard (eds.). Chicago: University of Chicago Press.

Belmonte, Cynthia (2000). "Foreign Sales Corporations, 1996." SOI Bulletin. 19(4, Spring):87-122.

Clausing, Kimberly A. (2001). "The Impact of Transfer Pricing on Intrafirm Trade." In International Taxation and Multinational Activity, James R. Hines, Jr. (ed.). Chicago: University of Chicago Press.

Desai, Mihir A., and James R. Hines Jr. (2000a). "The Design of Alternative Export Subsidy Regimes." University of Michigan. Working Paper.

- and - (2000b). "The Incidence of Export Subsidies as Revealed by Market Reactions." University of Michigan. Working Paper.

Desai, Mihir A., and James R. Hines, Jr. (2001). "Exchange Rates and TaxBased Export Promotion." In National Tax Association Ninety Third Annual 
Conference Proceedings, James R. Hines, Jr. (ed.). Washington, DC: National Tax Association.

Grubert, Harry (1998). "Taxes and the Division of Foreign Operating Income among Royalties, Interest, Dividends and Retained Earnings." Journal of Public Economics 68(2, May):269-290.

(2001). "Tax Planning by Companies and Tax Competition by Governments: Is There Evidence of Changes in Behavior?" In International Taxation and Multinational Activity, James R. Hines, Jr. (ed.). Chicago: University of Chicago Press.

- and John Mutti (1991). "Taxes, Tariffs, and Transfer Pricing in Multinational Corporate Decision Making." Review of Economics and Statistics 73(2, May):285-293.

_ W William C. Randolph, and Donald J. Rousslang (1996). "Country and Multinational Company Responses to the Tax Reform Act of 1986. National Tax Journal 49(3, September):341-358.

Hines, James R., Jr. (1991). The flight paths of migratory corporations. Journal of Accounting, Auditing, and Finance 6(4, Fall):447-479.

- (1994). "Credit and Deferral as International Investment Incentives." Journal of Public Economics 55(2, October):323-347.

- (1995). "Taxes, Technology Transfer, and the R\&D Activities of Multinational Firms." In The Effects of Taxation on Multinational Corporations, Martin Feldstein, James R. Hines, Jr., and R. Glenn Hubbard (eds.). Chicago: University of Chicago Press.

(1999a). "Lessons from Behavioral Responses to International Taxation." National Tax Journal 52(2, June):305-322.

(1999b). "The Case against Deferral: A Deferential Reconsideraiton." National Tax Journal 52(3, September):385-404.

- , and R. Glenn Hubbard (1990). "Coming Home to America: Dividend Repatriations by U.S. Multinationals." In Taxation in the Global Economy, Assaf Razin and Joel Slemrod (eds.). Chicago: University of Chicago Press.

—_ and Eric M. Rice (1994). "Fiscal Paradise: Foreign Tax Havens and American Business." Quarterly Journal of Economics 109(1, February):149-182.

Holik, Daniel S. (1995). "Interest-Charge Domestic International Sales Corporations, 1991." SOI Bulletin 14(1, Summer):46-57. $114-131$.

Hooper, Peter, Karen Johnson, and Jaime Marquez (1998). "Trade Elasticities for G-7 Countries." Federal Reserve Board of Governors International Finance Discussion Paper no. 609. April.

Horst, Thomas and Thomas Pugel (1977). The Impact of DISC on the Prices and Profitability of U.S. Exports." Journal of Public Economics 7(1, February):73-87. Hufbauer, Gary Clyde (1992). U.S. Taxation of International Income: Blueprint for Reform. Washington, DC: Institute for International Economics.

Rule, and Dean A. DeRosa (1997). "Costs and Benefits of the Export Source Rule." Tax Notes International, May 19:1661-1674.

Kemsley, Deen (1998). "The Effect of Taxes on Production Location." Journal of Accounting Research 36(2, Autumn):321-341.

Krugman, Paul R. and Maurice Obstfeld (1991). International Economics: Theory and Policy (2nd edition). New York: HarperCollins.

Macdonald, J. Ross (1999). "The Administration's Proposed Revision to §863(b): 
The Administration Fails to Make Its Best Case." Tax Management International Journal, 469-473.

Mataloni, Raymond J., Jr. (1999). "U.S. Multinational Companies: Operations in 1997." Survey of Current Business 79(7, July):8-35.

Mose, Vergie (1990). "Corporate Foreign Tax Credit, by Industry, 1984." SOI Bulletin 9(3):57-90.

Mutti, John and Harry Grubert (1984). "The Domestic International Sales Corporation and Its Effects." In The Structure and Evolution of Recent U.S. Trade Policy, Robert E. Baldwin and Anne O. Krueger (eds.). Chicago: University of Chicago Press.

Nutter, Sarah (1994). "Corporate Foreign Tax Credit, 1990: An Industry Focus." SOI Bulletin 13(4, Spring):78-106.

Oyola, José (2000). "Foreign Sales Corporation Beneficiaries: A Profile." Tax Notes, August 14:933-937.

Rangan, Subramanian and Robert Z. Lawrence (1993). "The Responses of U.S. Firms to Exchange Rate Fluctuations: Piercing the Corporate Veil." Brookings Papers on Economic Activity, 1993(2):341-369.

Rousslang, Donald J. (1994). "The Sales Source Rules for U.S. Exports: How Much Do They Cost?" Tax Notes, February 21:1047-1054.

Export Sour). "Comment on Hufbauer and DeRosa, Costs and Benefits of the

of U.S. Export-Enhancing Tax Provisions." IMF Staff Papers 41(4, December): 675-683.

Sawyer, W. Charles and Richard L. Sprinkle (1996). "The Demand for Imports and Exports in the U.S.: A Survey." Journal of Economics and Finance 20(1, Spring):147-178.

Scholes, Myron S. and Mark A. Wolfson (1992). Taxes and Business Strategy: A Planning Approach. Englewood Cliffs, NJ: Prentice Hall.

Scoffic, Matthew and Patrice Treubert (1999). "Corporate Income Tax Returns, 1996." SOI Bulletin 18(1, Summer):50-68.

States, William (1984). "Corporate Foreign Tax Credit, 1980: An Industry Focus." SOI Bulletin 3(1, Summer):63-84.

United States Department of the Treasury (1988). The Operation and Effect of the Domestic International Sales Corporation Legislation: July 1, 1981 to June 30, 1983. Internal Revenue Service (1992). "Foreign Sales Corporation Statistics for 1987." SOI Bulletin 11(4, Spring):59-67.

(1993). Report to the Congress on the Sales Source Rules.

(1997). The Operation and Effect of the Foreign Sales Corporation Legislation: July 1, 1992 to June 30, 1993.

United States Office of Management and Budget (2000). Budget of the United States Government, Fiscal Year 2001. Washington DC: Government Printing Office. 